\title{
Prevalence of Dietary Supplement Use by Athletes: Systematic Review and Meta-Analysis
}

\author{
Joseph J. Knapik ${ }^{1,2,3} \cdot$ Ryan A. Steelman ${ }^{2}$ - Sally S. Hoedebecke ${ }^{4}$. \\ Krista G. Austin ${ }^{1,3}$ - Emily K. Farina ${ }^{1,3}$ - Harris R. Lieberman ${ }^{1}$
}

Published online: 6 October 2015

(C) The Author(s) 2015. This article is published with open access at Springerlink.com

\begin{abstract}
Background Dietary supplements (DSs) are commercially available products consumed as an addition to the usual diet and are frequently ingested by athletes.

Objective Our objective was to examine the prevalence of DS use by athletes.

Data Sources PubMed, Ovid MEDLINE, OVID Healthstar, and Cumulative Index to Nursing and Allied Health were searched for original research articles published up to August 2014. Search terms included specific sports, specific DSs, and other terms.

Study Selection Studies were selected if they were written in English, involved athletes, and provided a quantitative assessment of the proportion of athletes using specific DSs. Summary Measure Percent of athletes using specific DSs. Synthesis of Data Methodological quality of studies was assessed by three reviewers using an 8-point scale that
\end{abstract}

The views expressed in this presentation are those of the authors and do not necessarily reflect the official policy of the Department of Defense, Department of the Army, US Army Medical Department or the US.

Electronic supplementary material The online version of this article (doi:10.1007/s40279-015-0387-7) contains supplementary material, which is available to authorized users.

Joseph J. Knapik

joseph.j.knapik.ctr@mail.mil

1 US Army Research Institute of Environmental Medicine, 10 General Greene Ave, Building 42, Natick, MA 01760, USA

2 US Army Public Health Center, Aberdeen Proving Ground, Gunpowder, MD, USA

3 Oak Ridge Institute for Education and Health, Belcamp, MD, USA

4 Serenity Hill Nutrition, Street, MD, USA included evaluations for sampling methods, sampling frame, sample size, measurement tools, bias, response rate, statistical presentation, and description of the participant sample. Where there were at least two investigations, metaanalysis was performed to obtain summary (pooled) prevalence estimates (SPEs) on (1) DS use prevalence by sport and sex, (2) DS use prevalence by elite versus nonelite athletic status, and (3) specific DS prevalence for all athletic groups combined. Meta-analyses included evaluations of homogeneity and publication bias.

Results A total of 159 unique studies met the review criteria. Methodological quality was generally low with an average \pm standard deviation of $43 \pm 16 \%$ of available rating points. There was low homogeneity for SPEs when compiled by sport, athletic status, and/or specific DSs. Contributing to the lack of homogeneity were differences in studies' objectives and types of assessments used (e.g., dietary surveys, interviews, questionnaires). Despite these limitations, the data generally indicated that elite athletes used DSs much more than their non-elite counterparts. For most DSs, use prevalence was similar for men and women except that a larger proportion of women used iron while a larger proportion of men used vitamin $\mathrm{E}$, protein, and creatine. No consistent change in use over time was observed because even the earliest investigations showed relatively high use prevalence.

Conclusion It was difficult to generalize regarding DS use by athletes because of the lack of homogeneity among studies. Nonetheless, the data suggested that elite athletes used dietary supplements far more than their non-elite counterparts; use was similar for men and women with a few exceptions; use appeared to change little over time; and a larger proportion of athletes used DSs compared with the general US population. Improvements in study methodology should be considered in future studies 
especially (1) defining DSs for participants; (2) querying for very specific DSs; (3) using a variety of reporting timeframes (e.g., daily, 2-6 times/week, 1 time/week and $<1$ time/week); (4) reporting the sampling frame, number of individuals solicited, and number responding; (5) reporting characteristics of volunteers (and non-volunteers, if available); and (6) using similar methods on several occasions to examine possible temporal trends among athletes.

\section{Key Points}

When dietary supplement use was compiled by sport, elite versus non-elite athletic status, and supplement type there was high variability in use prevalence among studies.

Elite athletes appeared to use dietary supplements much more than their non-elite counterparts.

For most dietary supplements, use prevalence appeared similar for men and women. Exceptions were that a larger proportion of women used iron and a larger proportion of men used vitamin E, protein, and creatine.

\section{Introduction}

A dietary supplement is a commercially available product that is consumed as an addition to the usual diet and includes vitamins, minerals, herbs (botanicals), amino acids, and a variety of other products [1]. Marketing claims for some dietary substances include improvements in overall health status, enhancement of cognitive or physical performance, increase in energy, loss of excess weight, attenuation of pain, and other favorable effects. The Dietary Supplement Health and Education Act (DSHEA) of 1994 [2] established the regulatory framework for dietary supplements in the US. Since this act became law, US sales of dietary supplements has increased from \$US4 billion in 1994 to \$US33 billion in 2012 [3, 4], an eightfold increase over 18 years. Global sales of supplements were \$US96 billion in 2012 and estimated at \$US104 billion in 2013 [5].

Patterns of dietary supplement use may differ in distinctive subpopulations. Athletes in different sports may use different dietary supplements depending on the nature of the physical activities they perform and the desired outcomes from the dietary supplements. Athletes often perform intense and prolonged physical activity and often report that their primary reason for using dietary supplements is to enhance performance or recover from exercise [6-14], although improving/maintaining health can also be an important rationale [15-19]. In contrast, the general population appears to consume dietary supplements primarily for health-related reasons, with only minor interest in performance enhancement [20,21]. Competitive athletes also need to be concerned with excessive use and possible adverse interactions due to polypharmacy [22, 23], and inadvertent doping due to the inadequate quality control of some dietary supplements [24, 25].

This paper presents a systematic literature review describing the prevalence of dietary supplement use in athletes. Where possible, meta-analyses were performed on dietary supplements by sport and sex, by elite versus nonelite athletic status, and by specific dietary supplements for all athletic groups combined. An older review on the prevalence of vitamin and mineral supplementation by athletes is also available [26].

\section{Methods}

This investigation generally followed the Preferred Reporting Items for Systematic Reviews and Meta-Analyses (PRISMA) guidelines [27].

\subsection{Information Sources and Search}

Literature searches were conducted in PubMed, Ovid MEDLINE (including OLDMEDLINE), OVID Healthstar, and Cumulative Index to Nursing and Allied Health Literature (CINAHL). No limitations were placed on the dates of the searches, and the final search was completed in August 2014. After reviewing PubMed medical subject headings for 'dietary supplements' and 'athletes', keywords selected for the search included athlete, sport, football, wrestling, soccer, ballet, dancing, running, gymnastics, swimming, basketball, hockey, tennis, softball, baseball, triathlete, triathlon, body building, weight lifting, volleyball, track, and crew. These keywords were combined with nutrition, dietary supplement, supplement, vitamin, mineral, amino acid, protein, herb, herbal, sport drink, sport bar, nutriceutical, neutraceuticals, food supplements, and food supplementation. To find additional studies, the reference lists of the articles obtained were searched, as was the literature database of an investigator with extensive experience with dietary supplement research. 


\subsection{Eligibility Criteria}

Articles were selected for the review if they were (1) written in English, (2) involved athletes, and (3) provided a quantitative assessment of the proportion of athletes using dietary supplements of any type, as defined by the DSHEA of 1994 [2]. Titles were first examined and abstracts were reviewed if the article appeared to involve athletes and either nutrition or dietary supplements. The full text of the article was retrieved if there was a possibility that dietary supplements were included within the investigation. Quantitative prevalence data could be contained within the text of the article, in tabular form, or presented in graphs. Data presented in graphic form were estimated. If the authors did not specifically reference dietary supplement prevalence, but data were available in the article to calculate it, then the article and the data were included in the review.

Not included in the review were studies that (1) examined athletic-related occupations (coaches, athletic trainers, physicians) or former athletes; (2) asked athletes about dietary supplements they would like to use (as opposed to actual use); (3) asked athletes about dietary supplement use they had observed; (4) mixed athletes with non-athletes, unless the athlete data were reported separately or could be calculated from the data provided; and (5) examined dietary supplement use during competitive events (because of the short timeframe and special, atypical circumstances). A number of studies that were identified did consider intake of dietary supplements in calculating nutritional intake of various athletic groups but did not specifically report the dietary supplement prevalence and so could not be used in this review. Abstracts, case studies, and case series were also not included. Stand-alone abstracts (without full-text articles) were excluded because they were difficult to locate, were generally not included in reference databases, and in many cases were not peer reviewed. Case studies and case series involved few individuals and were often published because they were atypical.

\subsection{Summary Measure}

The summary statistic was the percent of athletes using a specific dietary supplement. Data extracted from each study were (1) the number of athletes using a particular dietary supplement and (2) the number of athletes in the entire sample. Dividing the former by the latter and multiplying by $100 \%$ produced the use prevalence as a percent. Data from a number of studies required recalculation because authors expressed data as a percent of dietary supplement users rather than as a percent of the total sample.

\subsection{Considerations in Data Collection and Compilation}

A "unique study" was defined as a single data collection period. Multiple publications could be produced from a single unique study. When there were multiple publications from a unique study, all dietary supplement prevalence reported in any of the publications were included in the data extraction process; however, the publication was included only once in the analyses so as not to bias prevalence estimates to studies with more publications.

To be included in the review, the dietary supplement examined in the publication had to be specifically identified. That is, dietary supplements grouped into categories like 'antioxidant', 'pro-performance', 'herbal supplement', 'ergogenics', 'thermogenics', 'bodybuilding', and the like were not included in the data extraction process. Exceptions were the general category of vitamins and minerals, which were included since so many studies reported these. Sport drinks, sports bars, and energy drinks were also included in the review for the same reason, although these substances are classified as 'nutritional supplements' since they contain nutritional labeling as specified by the DSHEA. Brand names that contained multiple supplements were not included unless the brand name could be identified as having a single major identifiable dietary supplement.

To summarize the raw data, two major tables were constructed, one describing the methodology used by each study [see Table S1 in the Electronic Supplementary Material (ESM)], the other containing the prevalences of the most frequently reported dietary supplements (see Table S2 in the ESM).

\subsection{Methodological Quality Ratings}

Methodology quality of the investigations was assessed using the technique of Loney et al. [28], which was developed specifically for rating prevalence investigations. Studies were graded on an 8-point scale that included evaluations for sampling methods, sampling frame, sample size, measurement tools, bias, response rate, statistical presentation, and description of the participant sample. The eight items were rated as either 'yes' (1 point) or 'no' (no point), based on specific criteria. Thus, the maximum possible score was 8 . Three authors independently rated each of the selected articles. Following the independent evaluations, the reviewers met to examine the scores and reconcile major differences. The average score of the reviewers served as the methodological quality score. Scores were converted to a percent of the total available points by dividing the average score for each study by 8 and multiplying by $100 \%$. 


\subsection{Meta-Analyses}

We used the Comprehensive Meta-Analysis Statistical Package, Version 3.2 (Biostat, Englewood, NJ, USA) to perform meta-analyses on (1) dietary supplement prevalence by sport and sex; (2) dietary supplement prevalence by elite versus non-elite athletic status; and (3) prevalence by specific dietary supplements for all athletic groups combined. These analyses required at least two studies and only studies that queried athletes about 'current', 'usual', or 'regular' use of dietary supplements were considered so that the reporting timeframe was similar. Studies asking about the use of dietary supplements at other times (e.g., last 2 months, last 6 months, etc.) were not included in the meta-analyses. For the sport-specific meta-analyses, the sport had to be explicit (e.g., football, basketball, tennis). If sports were grouped into broad categories (e.g., 'combat sports', 'racquet sports', 'speed sports', 'power sports', 'endurance sports', 'ball sports'), they were not included. Elite athletes were defined as those competing professionally, at national or international level. Athletes competing at high schools, colleges, or universities were not considered elite. Only studies that involved adults and provided separate prevalence data for men and women were included in the elite versus nonelite meta-analyses. If sample sizes were not provided for a particular group or subgroup, the study could not be included because sample sizes are required for metaanalysis.

For all meta-analyses, we used a random model that considered users and non-users of dietary supplements to produce a summary prevalence estimate (SPE) and a summary $95 \%$ confidence interval (S95\% CI) that represented the pooled data of all the individual investigations. Homogeneity of the pooled prevalence estimates was assessed using the $Q$ - and the $I^{2}$-statistics [29]. $I^{2}$ indicated the percent of heterogeneity among studies, with smaller values denoting more homogeneity and larger values less homogeneity. In calculating $I^{2}$, negative values were set to zero, which indicated very little heterogeneity [30]. Where there were four or more studies, publication bias was assessed by examining the symmetry of study data in funnel plots (1/standard error of prevalences vs. logit of the prevalences) and further appraising the information with the trim and fill evaluation. The trim and fill evaluation imputes the number of 'missing' studies in the funnel plot and re-computes an adjusted SPE and S95\% CI with the 'missing' studies included [31]. Where there were fewer than four studies, symmetry of studies about the funnel plot could not be interpreted.

\section{Results}

Figure 1 shows the number of publications included and excluded at each stage of the literature search. The initial search identified 16,694 citations, 5926 of which were duplicate publications (from different databases) that were removed. Based on a review of titles and abstracts, 311 full articles were obtained for review, and subsequently 136 were removed for not having information on prevalence or meeting the exclusion criteria. A total of 175 studies were further reviewed, but 16 of these did not contain useful data because of the manner in which the dietary supplements were categorized ('antioxidant', 'pro-performance', 'herbal supplement', etc.). In total, 159 unique studies (and 165 published papers) finally met the inclusion criteria. Two unique studies produced two reports each [32-35], one resulted in three publications [36-38], and one resulted in four articles [12, 39-41].

\subsection{Study Methodologies}

Table $\mathrm{S} 1$ in the ESM shows the participants and methods in the 159 unique investigations. In terms of specific sports, there were 14 studies of football players [7, 8, 42-53]; 12 of swimmers [7, 44, 45, 48, 54-61] and soccer players [7, $44,45,48,52,62-68]$; ten of body builders [6, 69-77] and basketball players [7, 42-46, 52, 78-80]; nine of volleyball players [7, 43-47, 49, 52, 81]; eight of wrestlers [7, 42-45, $47,48,82]$ and tennis players [7, 43-48, 52]; seven of ballet dancers [83-89] and gymnasts [7, 44, 45, 90-93]; six with marathoners [36, 63, 94-97], baseball players [7, 43, $45,46,48,52]$, triathletes [63, 98-102], and golfers [7, 4447, 52]; five with dancers [47, 89, 103-105]; four with ultra-marathoners [106-109]; three with runners [110 112], figure skaters [15, 113, 114], alpine skiers [44, 48, 115], cheerleaders [7, 45, 48], cross-country runners [7, 44, 52], lacrosse players [44, 45, 48], softball players [7, 43, 52], and ice hockey players [44, 116, 117]; two with field hockey players $[45,48]$; and one each with aerobic dancers [118], cyclists [119], divers [45], fencers [45], Nordic skiers [115], rugby players [120], sailors [121], speed skaters [122], synchronized swimmers [89], surfers [123], table tennis players [124], and weight lifters [63]. Eight studies involved athletes in 'track and field' sports without defining the specific sport [7, 16, 43, 44, 46, 104, 125, 126]. Other studies looked at groups of sports with elite athletes [9, 13, 14, 18, 19, 34, 35, 127-138] (including Olympic athletes [32, 139-145]), university or college athletes [11, 146-156], high school athletes [157-162], fitness/health/ wellness club or gym users [10, 17, 95, 163-169], and other groups of athletes [12, 23, 79, 170-177]. 


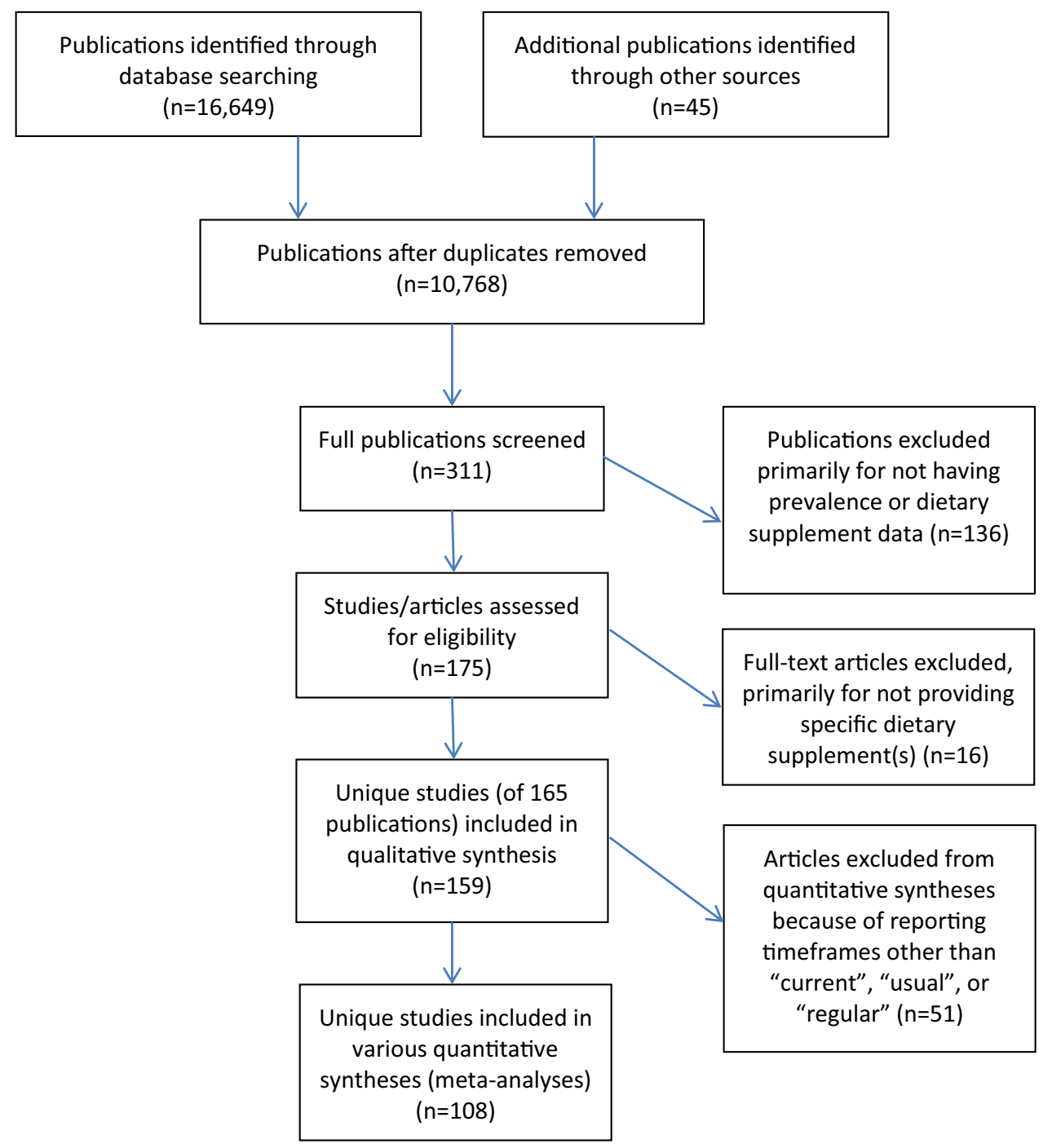

Fig. 1 Publications included and excluded at each stage of literature review

The data in Table S1 in the ESM indicate that 63 of 159 unique studies ( $40 \%$ ) used questionnaires to obtain dietary supplement information from participants, and these were either focused on general or more specific (e.g., creatine or protein) dietary supplement. A total of 63 studies (40\%) centered on topics other than dietary supplements but included some items on general or specific dietary supplement use. Some studies used dietary records, asking athletes to record what they consumed in periods of 1 day $(n=1), 3$ days $(n=26), 4$ days $(n=2), 7$ days $(n=10)$, or 14 days $(n=1)$, with some studies collecting data over several periods $(n=6)$. A few investigations used dietary recall $(n=7)$ and/or food frequency questionnaires $(n=4)$. Some studies interviewed athletes $(n=7)$ or used interviews in combination with other methods $(n=3)$. In a few cases $(n=3)$, the methods for collecting the study data were not stated.
The data in Table S1 of the ESM indicate that the athletes' reporting timeframe differed among studies. There were 108 studies $(68 \%)$ that involved current, regular, or usual use of dietary supplements. Some studies focused on dietary supplement use in specific periods of time including the last 3 days $(n=1)$, last month $(n=5)$, last 2 months $(n=1)$, last 3 months $(n=3)$, last 6 months $(n=6)$, last 12 months $(n=5)$, in the bulking phase of body building $(n=1)$, for $>6$ months in the previous 3 years $(n=1)$, or use in athletes' college sports careers $(n=1)$. A number of studies asked about dietary supplement use at any time, currently or in the past $(n=14)$. In some studies, the reporting timeframe was not clear $(n=13)$.

Table S1 in the ESM shows that the proportion of solicited athletes participating in the investigations ranged from 7 to $100 \%$, with 36 investigations ( $23 \%$ ) achieving $\geq 66 \%$ participation and 32 studies $(20 \%)$ with 
Table 1 Methodological quality scores at various publication times

\begin{tabular}{llll}
\hline $\begin{array}{l}\text { Publication } \\
\text { date (year } \\
\text { grouping) }\end{array}$ & $\begin{array}{l}\text { Studies } \\
(n)\end{array}$ & $\begin{array}{l}\text { Methodological } \\
\text { quality score } \\
\text { (mean } \pm \text { SD) }\end{array}$ & $\begin{array}{l}\text { One way analysis } \\
\text { of variance } \\
p \text { value }\end{array}$ \\
\hline $1969-1989$ & 38 & $37 \pm 15$ & 0.04 \\
$1990-1999$ & 32 & $45 \pm 14$ & \\
$2000-2009$ & 50 & $43 \pm 13$ & \\
$2010-2014$ & 39 & $46 \pm 16$ & \\
\hline
\end{tabular}

$S D$ standard deviation

participation of $<66 \%$. In 89 studies (56\%), the proportion of the solicited athletes participating in the study was not specified. In two cases (1\%), the nature of the study was such that participation could not be determined (i.e., a case-control study and a study that only reported the proportion of high schools participating).

As shown in Table $\mathrm{S} 1$ in the ESM, rating from the methodological quality reviews ranged from 8 to $83 \%$ of available points, with an average \pm standard deviation rating of $43 \pm 16 \%$. Only 54 studies $(34 \%$ ) had scores of $\geq 50 \%$ and only eight studies $(5 \%)$ had scores of $\geq 70 \%$. Very few investigations drew true random samples or specified a sampling frame. In some cases, lower methodological quality was associated with the fact that the study was not focused on dietary supplement prevalence. For example, studies on medication use or 'doping' [23, $135,142,143,176]$ and studies on the nutritional intake $[54,62,81,133]$ included information on dietary supplement prevalence, but this was not the main purpose of the investigation. Table 1 shows that the methodological quality scores in the studies published in the 1969-1989 period were slightly lower than those published later, but the overall difference between the two publication periods (1969-1989 vs. 1990-2014) was only $6 \%$.

\subsection{Dietary Supplement Use Reported in Individual Investigations}

Table S2 in the ESM shows the prevalence of dietary supplement use documented in each study. Information on the prevalence of any dietary supplement use was included in 95 studies $(60 \%)$. The use of any vitamins and/or minerals was reported in 67 investigations (42\%), multivitamin/multimineral use in 67 studies (42\%), and specific vitamins and/or minerals in 70 studies (44\%). Amino acid and/or protein supplementation was reported in 82 investigations $(52 \%)$, while creatine use was reported in 50 (31\%). There were 27 studies $(17 \%)$ that reported on specific herbal supplements. Sports drink use was reported in 33 studies (21\%), sports bar use in 18 studies (11\%), substances containing omega- 3 fatty acids in 11 studies
(7\%), caffeine use in eight studies (5\%), and energy drink consumption in seven studies $(4 \%)$.

\subsection{Meta-Analyses on Dietary Supplement Prevalence}

Table 2 presents the meta-analyses conducted on studies that provided data by sport, sex, and specific dietary supplements and where there were at least two investigations involving specific dietary supplements. Very few investigations provided the necessary data for conducting metaanalyses by these categories. Some studies that would have been appropriate for these analyses did not provide sample sizes by sport [43-45, 47, 48, 52], while other studies that did provide sport and sample size did not separate dietary supplement data by sex [56, 58, 60, 61, 96, 106, 109, 112, $113,118,121]$. Where appropriate data were available, many of the SPEs had wide S95 \% CIs and low homogeneity. Of the 31 analyses in Table 2, only about half $(n=16)$ had $Q$ statistic $p$ values $>0.05$, and $29 \%(n=9)$ had $I^{2}$ values $\leq 50 \%$. Despite this, the data suggested that the largest prevalence of dietary supplement use was among male soccer players and body builders, with other groups having lower use prevalences.

Table 3 shows the results of the meta-analyses of selected dietary supplements (any dietary supplements, multivitamins/multiminerals, and vitamin C) comparing sex-specific elite and non-elite athletic groups. A wide variety of sports were represented in these comparisons. With few exceptions, the SPEs demonstrated low homogeneity, with only 4 of the 12 analyses (33\%) having $Q$ statistic $p$ values $>0.05$ and $I^{2}$ values $\leq 50 \%$. There was generally little indication of publication bias, with the exception of any dietary supplement use in elite athletes. For elite athletes, the trim and fill adjusted SPE for any dietary supplement use was lower than the unadjusted values, but still higher than that of the non-elite athletes. Compared with non-elite athletes, a larger proportion of elite athletes also used multivitamins/multiminerals and vitamin $\mathrm{C}$.

An attempt was made to examine dietary supplement use in all athletic groups combined; the results are shown in Table 4. There was very little homogeneity among the studies. Of the 61 analyses, only two had a $Q$ statistic $p$ value $>0.05$ and only one had an $I^{2} \leq 50 \%$. Despite this, the SPEs seem to indicate that the overall prevalence of dietary supplement use was high, with about $60 \%$ of athletes using dietary supplements of any type and with vitamin/minerals, multivitamins/multiminerals, vitamin $\mathrm{C}$, protein, sport drinks, and sport bars among the most commonly used. Male and female athletes had similar SPEs for most dietary supplements, with a few exceptions: compared with men, a larger proportion of women used 


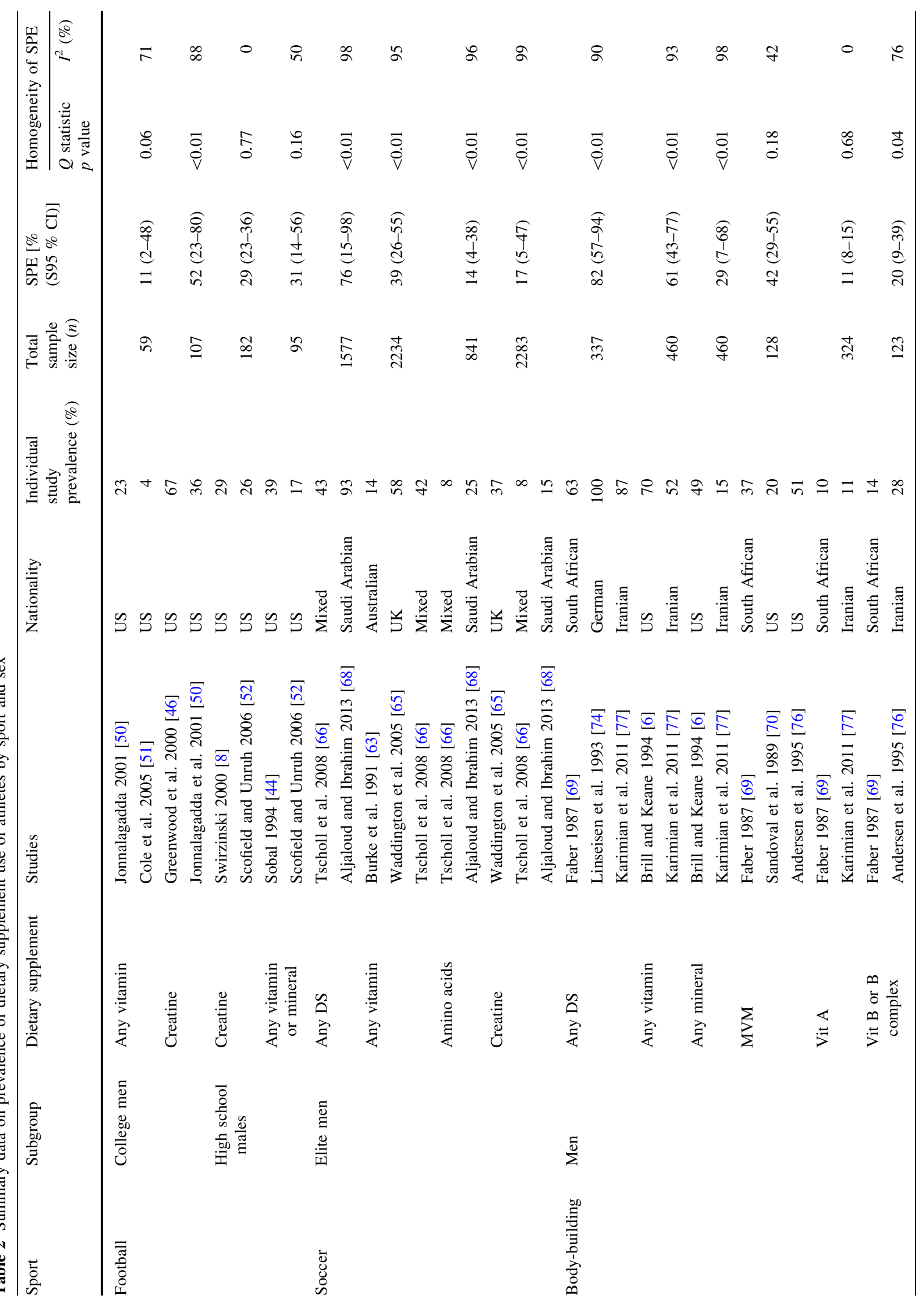




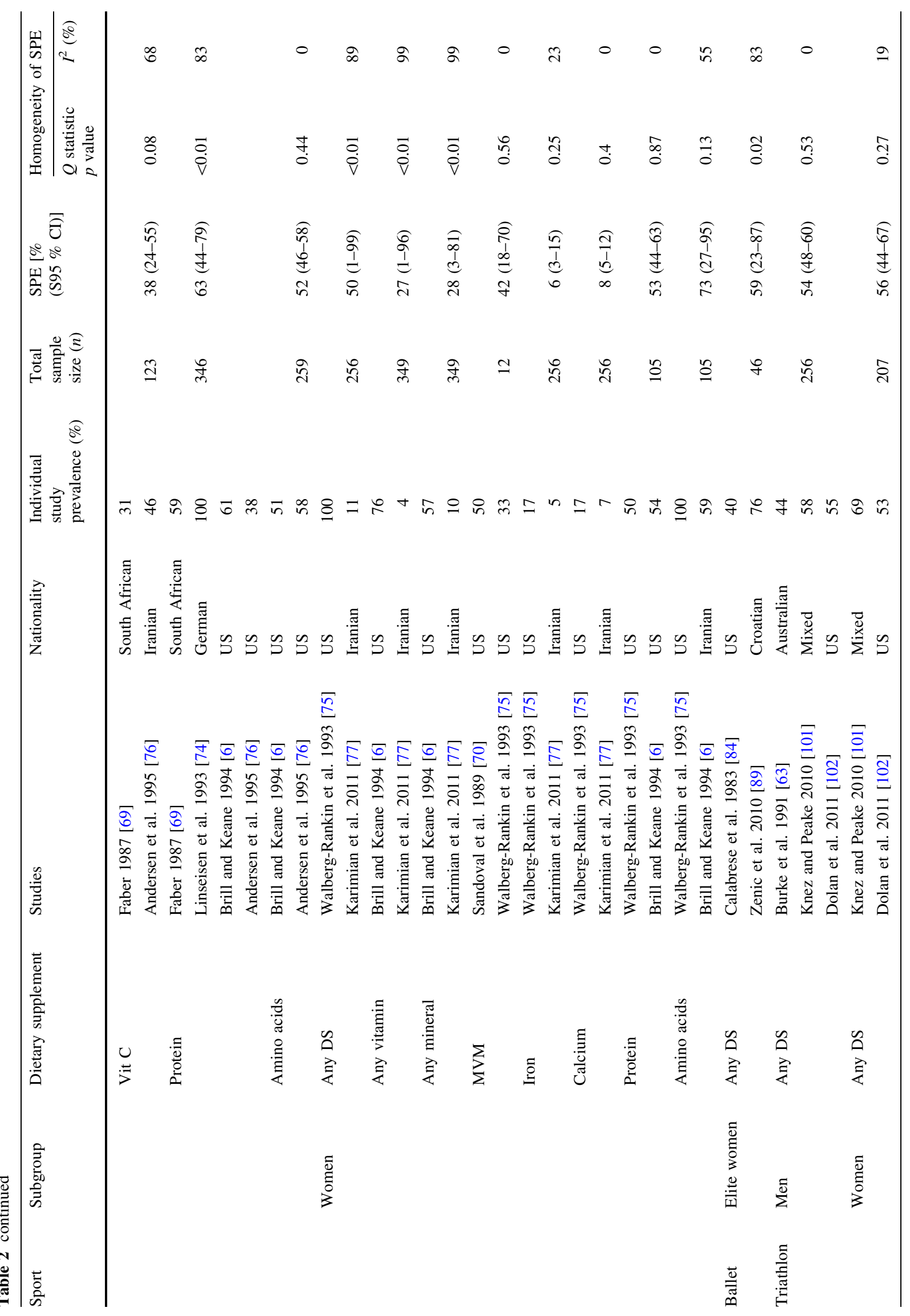




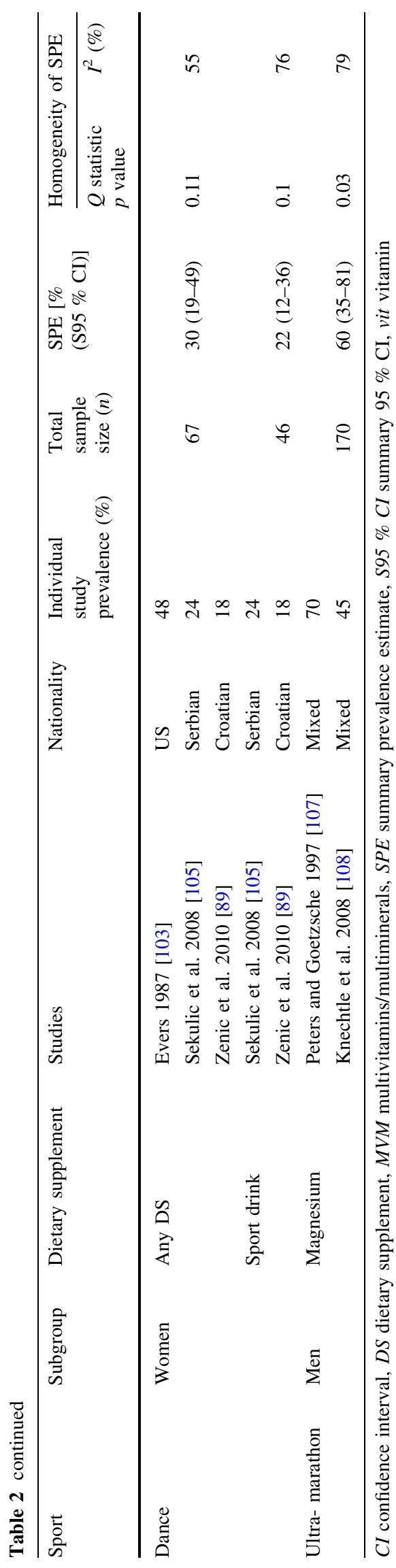

iron and a smaller proportion used vitamin E, protein, and creatine. There was some indication of publication bias but these cases had little effect on the trim and fill adjusted SPEs.

\section{Discussion}

This review illustrates the difficulty in obtaining a comprehensive description of the prevalence of dietary supplement use in athletes. Studies on this topic have used different data collection methods (e.g., dietary surveys, interviews, questionnaires), collected data on different dietary supplements, and used different reporting timeframes. The methodological quality of the studies was generally very low, with only $34 \%$ of studies acquiring even half the available points on the Loney et al. [28] checklist. Methodological quality of the studies published after the 1990s improved slightly, but average improvement was only an additional $6 \%$ of available points (37 vs. $43 \%$ ). Using meta-analysis, an attempt was made to summarize the data by sex and sport, but few studies reported use of the same dietary supplements, and where this was the case the prevalence values in many individual studies varied widely (low homogeneity), resulting in broad S95 \% CIs. Nonetheless, the tables in the present study provide a comprehensive summary of available data on the use of dietary supplements by athletes.

When comparisons were made between elite and nonelite athletes, the SPEs suggested that elite athletes tended to use dietary supplements to a greater extent than the nonelite athletes. However, prevalence ranges among studies were still wide, demonstrating low homogeneity. Further, this comparison was complicated by differences in the types of sports that might be included in the two groups. Athletes involved in different sports might be expected to use different dietary supplements, although the combined data on specific dietary supplements in specific sports was too sparse to test this hypothesis (Table 2). The sex comparisons within the elite/non-elite groups might be more appropriate because the comparisons involve similar (although not identical) sports. However, the prevalence values still varied widely and the SPEs lacked homogeneity. Nonetheless, examining the individual study prevalences and the SPEs within the elite or non-elite groups suggested little difference between men and women in overall prevalence of dietary supplement use.

Like comparisons by sport and elite/non-elite status, the attempt to summarize the sex-specific prevalences of particular dietary supplements for all studies on athletes suffered from a lack of homogeneity. Nonetheless, SPEs appeared to be similar between men and women, with a few exceptions. Compared with men, a larger proportion of 


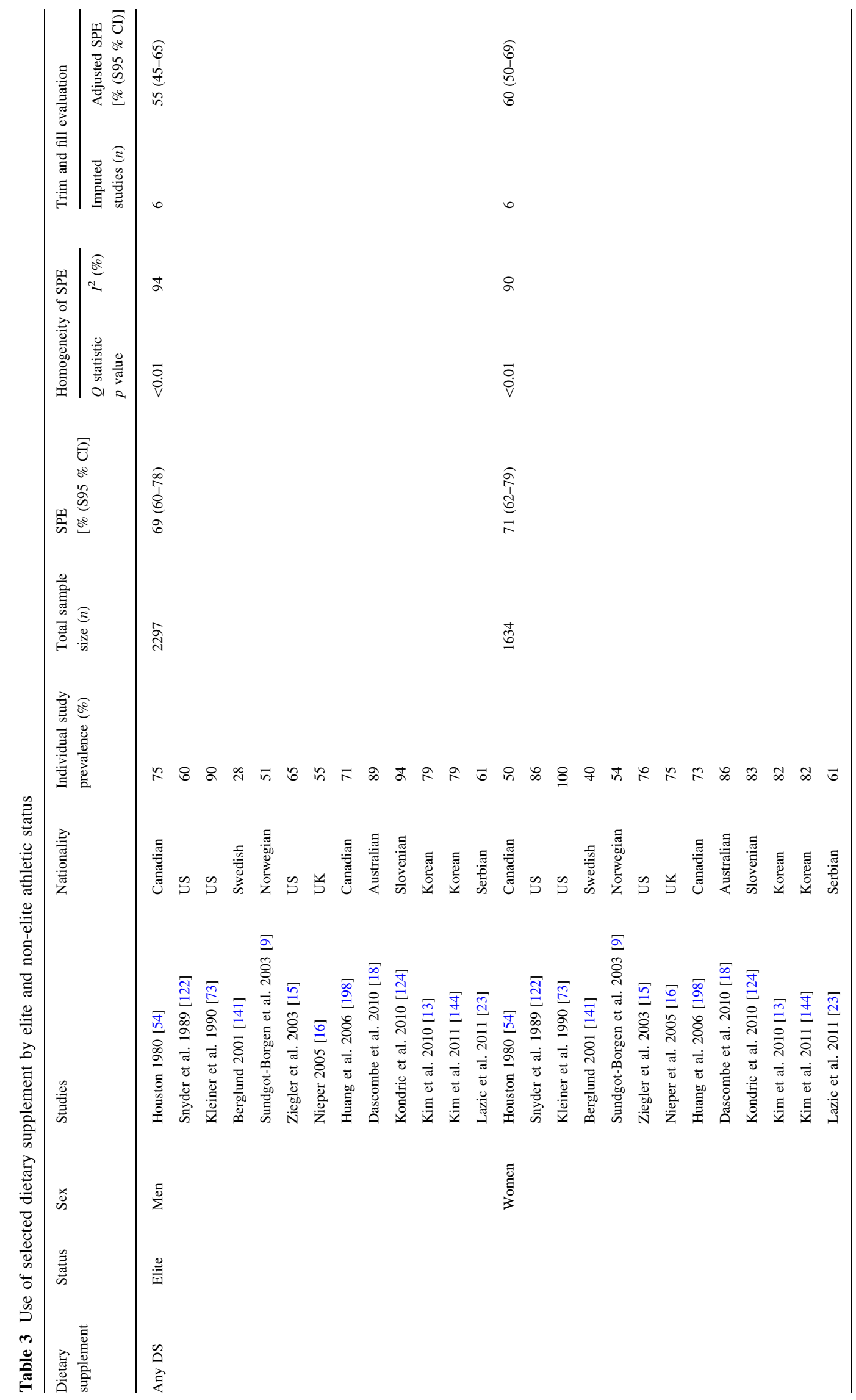




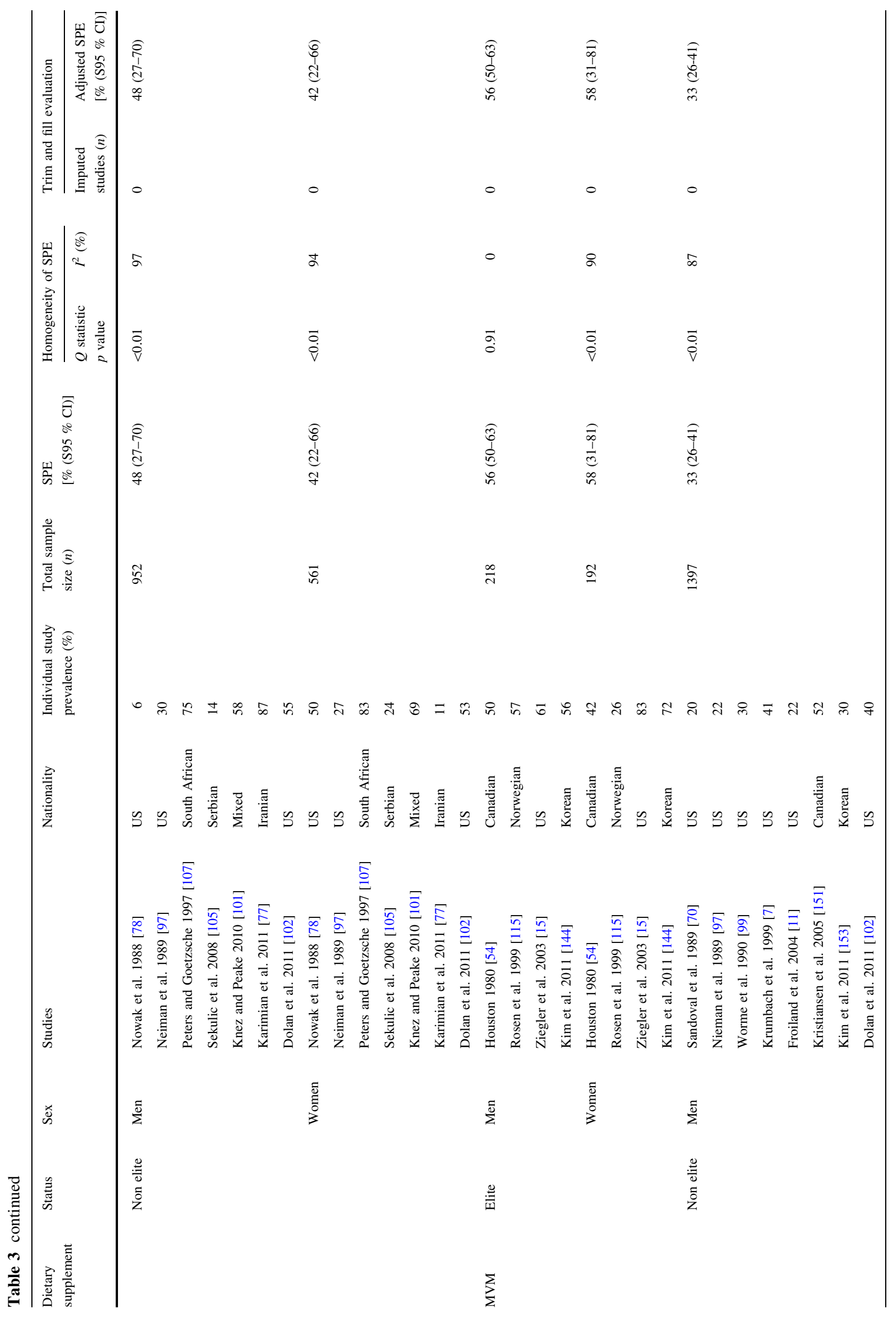




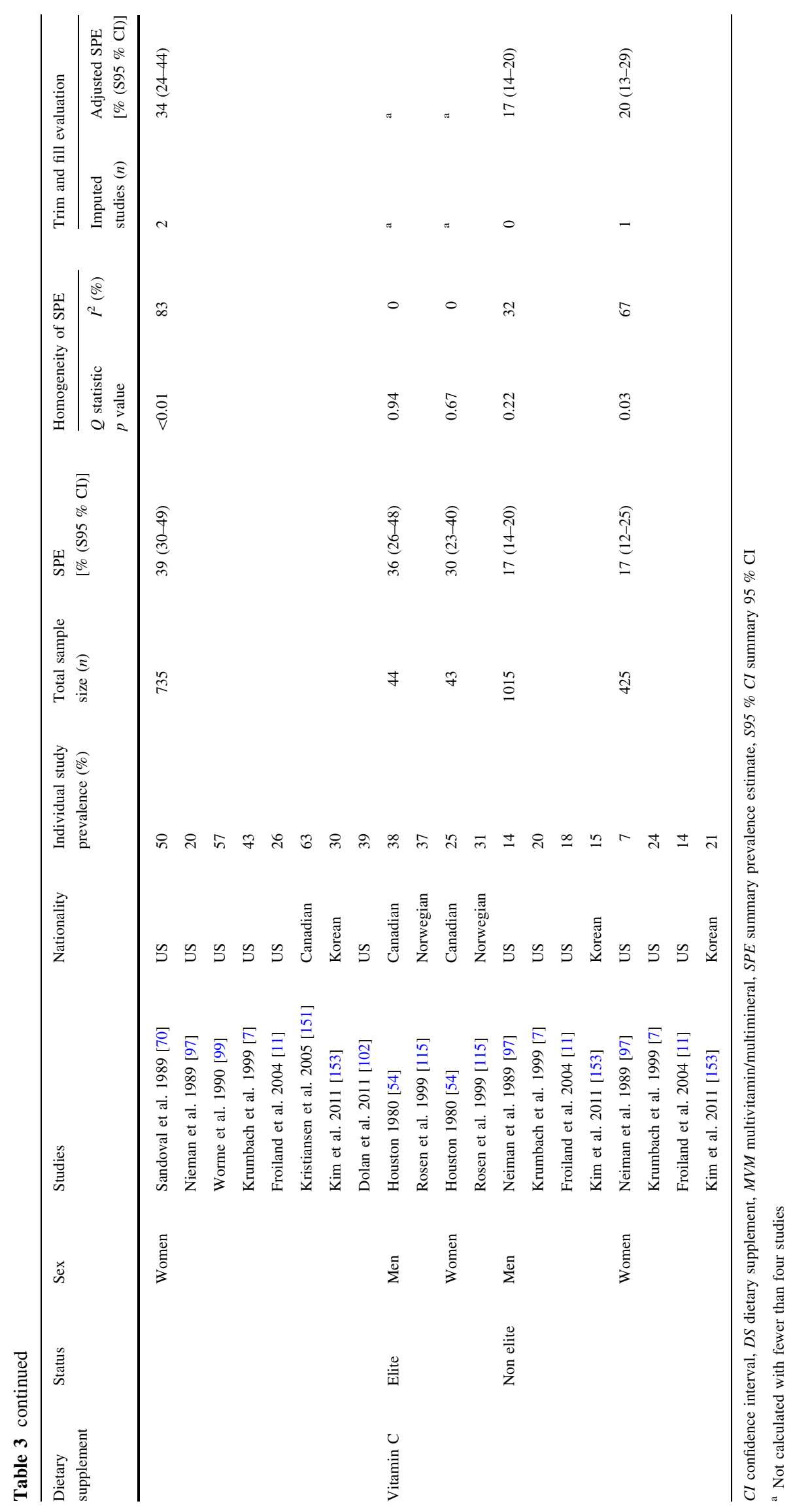


Table 4 Prevalence of dietary supplement use in combined athletic groups

\begin{tabular}{|c|c|c|c|c|c|c|c|}
\hline \multirow[t]{2}{*}{ Dietary supplement } & \multirow[t]{2}{*}{ Sex } & \multirow{2}{*}{$\begin{array}{l}\text { Studies } \\
(n)\end{array}$} & \multirow{2}{*}{$\begin{array}{l}\text { SPE }[\%(\mathrm{~S} 95 \% \\
\mathrm{CI})]\end{array}$} & \multicolumn{2}{|c|}{ Homogeneity of SPE } & \multicolumn{2}{|c|}{ Trim and fill evaluation } \\
\hline & & & & $\begin{array}{l}Q \text { statistic } \\
p \text { value }\end{array}$ & $\overline{I^{2}}$ & $\begin{array}{l}\text { Imputed studies } \\
(n)\end{array}$ & $\begin{array}{l}\text { Adjusted SPE [\% (S95\% } \\
\text { CI)] }\end{array}$ \\
\hline \multirow[t]{3}{*}{ Any DS } & $\begin{array}{l}\mathrm{M} \text { and } \\
\mathrm{F}\end{array}$ & 61 & $60(55-64)$ & $<0.01$ & 97 & 4 & $58(54-63)$ \\
\hline & M & 34 & $62(56-69)$ & $<0.01$ & 95 & 2 & $60(54-67)$ \\
\hline & $\mathrm{F}$ & 31 & $58(50-65)$ & $<0.01$ & 92 & 2 & $57(49-64)$ \\
\hline \multirow[t]{3}{*}{ Any vitamin/mineral } & $\begin{array}{l}\mathrm{M} \text { and } \\
\mathrm{F}\end{array}$ & 22 & $50(43-57)$ & $<0.01$ & 91 & 1 & $49(42-57)$ \\
\hline & M & 9 & $50(41-60)$ & $<0.01$ & 85 & 2 & $47(37-57)$ \\
\hline & $\mathrm{F}$ & 14 & $52(43-62)$ & $<0.01$ & 82 & 1 & $49(40-59)$ \\
\hline \multirow[t]{3}{*}{ MVM } & $\begin{array}{l}\mathrm{M} \text { and } \\
\mathrm{F}\end{array}$ & 44 & $34(30-40)$ & $<0.01$ & 96 & 2 & $33(28-38)$ \\
\hline & M & 21 & $37(31-44)$ & $<0.01$ & 90 & 2 & $36(19-32)$ \\
\hline & $\mathrm{F}$ & 25 & $36(29-44)$ & $<0.01$ & 88 & 2 & $35(26-44)$ \\
\hline \multirow[t]{3}{*}{ Vitamin A } & $\begin{array}{l}\mathrm{M} \text { and } \\
\mathrm{F}\end{array}$ & 10 & $6(4-7)$ & $<0.01$ & 91 & 1 & $6(4-10)$ \\
\hline & M & 6 & $4(2-8)$ & $<0.01$ & 88 & 1 & $5(2-9)$ \\
\hline & $\mathrm{F}$ & 5 & $3(1-10)$ & $<0.01$ & 86 & 2 & $5(2-13)$ \\
\hline \multirow[t]{3}{*}{$\begin{array}{l}\text { Vitamin B or B } \\
\text { complex }\end{array}$} & $\begin{array}{l}\mathrm{M} \text { and } \\
\mathrm{F}\end{array}$ & 24 & $17(12-23)$ & $<0.01$ & 96 & 0 & $17(12-23)$ \\
\hline & M & 12 & $18(11-28)$ & $<0.01$ & 95 & 0 & $18(11-28)$ \\
\hline & $\mathrm{F}$ & 10 & $15(9-23)$ & $<0.01$ & 85 & 1 & $17(11-26)$ \\
\hline \multirow[t]{3}{*}{ Vitamin C } & $\begin{array}{l}M \text { and } \\
F\end{array}$ & 34 & $32(26-39)$ & $<0.01$ & 96 & 1 & $33(27-39)$ \\
\hline & M & 18 & $34(25-44)$ & $<0.01$ & 97 & 0 & $34(25-44)$ \\
\hline & $\mathrm{F}$ & 20 & $31(25-38)$ & $<0.01$ & 84 & 8 & $41(35-49)$ \\
\hline \multirow[t]{3}{*}{ Vitamin D } & $\begin{array}{l}\mathrm{M} \text { and } \\
\mathrm{F}\end{array}$ & 10 & $7(3-15)$ & $<0.01$ & 96 & 0 & $7(3-15)$ \\
\hline & M & 5 & $10(3-32)$ & $<0.01$ & 94 & 0 & $10(3-32)$ \\
\hline & $\mathrm{F}$ & 3 & $7(2-28)$ & $<0.01$ & 86 & a & a \\
\hline \multirow[t]{3}{*}{ Vitamin E } & $\begin{array}{l}\mathrm{M} \text { and } \\
\mathrm{F}\end{array}$ & 24 & $13(10-18)$ & $<0.01$ & 94 & 3 & $16(12-21)$ \\
\hline & M & 10 & $14(8-23)$ & $<0.01$ & 92 & 1 & $16(10-25)$ \\
\hline & $\mathrm{F}$ & 7 & $8(4-15)$ & $<0.01$ & 79 & 1 & $9(5-17)$ \\
\hline \multirow[t]{3}{*}{ Iron } & $\begin{array}{l}\mathrm{M} \text { and } \\
\mathrm{F}\end{array}$ & 30 & $17(12-23)$ & $<0.01$ & 95 & 0 & $17(12-23)$ \\
\hline & M & 10 & $11(5-24)$ & $<0.01$ & 96 & 0 & $11(5-24)$ \\
\hline & $\mathrm{F}$ & 18 & $23(15-34)$ & $<0.01$ & 94 & 0 & $23(15-34)$ \\
\hline \multirow[t]{3}{*}{ Calcium } & $\begin{array}{l}\mathrm{M} \text { and } \\
\mathrm{F}\end{array}$ & 25 & $12(8-18)$ & $<0.01$ & 94 & 5 & $15(11-22)$ \\
\hline & M & 7 & $20(7-47)$ & $<0.01$ & 97 & 0 & $20(7-47)$ \\
\hline & $\mathrm{F}$ & 14 & $17(11-25)$ & $<0.01$ & 90 & 3 & $21(14-30)$ \\
\hline \multirow[t]{3}{*}{ Zinc } & $\begin{array}{l}\mathrm{M} \text { and } \\
\mathrm{F}\end{array}$ & 10 & $7(5-10)$ & $<0.01$ & 80 & 0 & $7(5-10)$ \\
\hline & M & 5 & $7(4-12)$ & 0.01 & 68 & 0 & $7(4-12)$ \\
\hline & $\mathrm{F}$ & 5 & $5(2-13)$ & $<0.01$ & 81 & 2 & $8(3-17)$ \\
\hline \multirow[t]{3}{*}{ Protein } & $\begin{array}{l}\mathrm{M} \text { and } \\
\mathrm{F}\end{array}$ & 33 & $27(20-35)$ & $<0.01$ & 98 & 0 & $27(20-35)$ \\
\hline & M & 20 & $36(25-49)$ & $<0.01$ & 78 & 1 & $37(25-50)$ \\
\hline & $\mathrm{F}$ & 15 & $12(7-22)$ & $<0.01$ & 95 & 0 & $12(7-22)$ \\
\hline
\end{tabular}


Table 4 continued

\begin{tabular}{|c|c|c|c|c|c|c|c|}
\hline \multirow[t]{2}{*}{ Dietary supplement } & \multirow[t]{2}{*}{ Sex } & \multirow{2}{*}{$\begin{array}{l}\text { Studies } \\
(n)\end{array}$} & \multirow{2}{*}{$\begin{array}{l}\text { SPE }[\%(\text { S } 95 \% \\
\text { CI)] }\end{array}$} & \multicolumn{2}{|c|}{ Homogeneity of SPE } & \multicolumn{2}{|c|}{ Trim and fill evaluation } \\
\hline & & & & $\begin{array}{l}Q \text { statistic } \\
p \text { value }\end{array}$ & $I^{2}$ & $\begin{array}{l}\text { Imputed studies } \\
(n)\end{array}$ & $\begin{array}{l}\text { Adjusted SPE [\% (S95 \% } \\
\text { CI)] }\end{array}$ \\
\hline \multirow[t]{3}{*}{ Amino acid } & $\begin{array}{l}\mathrm{M} \text { and } \\
\mathrm{F}\end{array}$ & 24 & $15(12-20)$ & $<0.01$ & 97 & 0 & $15(12-20)$ \\
\hline & M & 15 & $15(9-23)$ & $<0.01$ & 96 & 0 & $15(9-23)$ \\
\hline & $\mathrm{F}$ & 10 & $10(3-23)$ & $<0.01$ & 96 & 0 & $10(3-23)$ \\
\hline \multirow[t]{3}{*}{ Creatine } & $\begin{array}{l}\mathrm{M} \text { and } \\
\mathrm{F}\end{array}$ & 24 & $14(10-20)$ & $<0.01$ & 97 & 0 & $14(10-20)$ \\
\hline & M & 18 & $17(11-26)$ & $<0.01$ & 97 & 3 & $20(13-30)$ \\
\hline & $\mathrm{F}$ & 14 & $3(1-4)$ & $<0.01$ & 53 & 5 & $3(2-6)$ \\
\hline \multirow[t]{3}{*}{ Echinacea } & $\begin{array}{l}\mathrm{M} \text { and } \\
\mathrm{F}\end{array}$ & 7 & $12(4-29)$ & $<0.01$ & 97 & 0 & $12(4-29)$ \\
\hline & M & 3 & $11(3-40)$ & $<0.01$ & 87 & $\mathrm{a}$ & a \\
\hline & $\mathrm{F}$ & 4 & $13(2-60)$ & $<0.01$ & 96 & 0 & $13(2-60)$ \\
\hline \multirow[t]{3}{*}{ Ginseng } & $\begin{array}{l}\mathrm{M} \text { and } \\
\mathrm{F}\end{array}$ & 9 & $8(5-14)$ & $<0.01$ & 96 & 1 & $9(5-15)$ \\
\hline & M & 5 & $10(6-17)$ & $<0.01$ & 89 & 0 & $10(6-17)$ \\
\hline & $\mathrm{F}$ & 5 & $8(3-20)$ & $<0.01$ & 94 & 0 & $8(3-20)$ \\
\hline \multirow[t]{3}{*}{ Sport drink } & $\begin{array}{l}\mathrm{M} \text { and } \\
\mathrm{F}\end{array}$ & 17 & $28(18-24)$ & $<0.01$ & 98 & 0 & $28(18-24)$ \\
\hline & M & 10 & $44(24-66)$ & $<0.01$ & 96 & 0 & $44(24-66)$ \\
\hline & $\mathrm{F}$ & 8 & $35(22-51)$ & $<0.01$ & 89 & 0 & $35(22-51)$ \\
\hline \multirow[t]{3}{*}{ Sport bar } & $\begin{array}{l}\mathrm{M} \text { and } \\
\mathrm{F}\end{array}$ & 9 & $34(22-47)$ & $<0.01$ & 95 & 0 & $34(22-47)$ \\
\hline & M & 7 & $28(14-56)$ & $<0.01$ & 96 & 0 & $28(14-28)$ \\
\hline & $\mathrm{F}$ & 3 & $32(12-62)$ & $<0.01$ & 96 & 0 & $32(12-62)$ \\
\hline \multirow[t]{3}{*}{$\begin{array}{c}\Omega \text {-3-fatty acid } \\
\text { supplement }\end{array}$} & $\begin{array}{l}\mathrm{M} \text { and } \\
\mathrm{F}\end{array}$ & 6 & $14(8-24)$ & $<0.01$ & 94 & 1 & $18(10-28)$ \\
\hline & M & 4 & $21(12-31)$ & $<0.01$ & 91 & 1 & $25(15-39)$ \\
\hline & $\mathrm{F}$ & 3 & $20(12-32)$ & $<0.01$ & 79 & a & a \\
\hline Energy drink ${ }^{b}$ & $\begin{array}{l}\mathrm{M} \text { and } \\
\mathrm{F}\end{array}$ & 3 & $34(26-43)$ & $<0.01$ & 71 & a & $\mathrm{a}$ \\
\hline \multirow[t]{3}{*}{ Caffeine } & $\begin{array}{l}\mathrm{M} \text { and } \\
\mathrm{F}\end{array}$ & 4 & $29(16-46)$ & $<0.01$ & 94 & 1 & $24(2-41)$ \\
\hline & M & 2 & $20(16-26)$ & 0.73 & 0 & a & a \\
\hline & $\mathrm{F}$ & 2 & $21(16-24)$ & 0.14 & 54 & a & a \\
\hline
\end{tabular}

$D S$ dietary supplement, $F$ females, $M$ males, $M V M$ multivitamin/multimineral, SPE summary prevalence estimate, S95\% CI summary $95 \%$ confidence interval

${ }^{a}$ Not calculated with fewer than four studies

b No study reported men and women separately

women appeared to use iron supplements. A much larger proportion of active women appear to be iron deficient compared with active men [178], and the recommended daily allowances for iron are more than twice as high for premenopausal women $(18 \mathrm{mg} /$ day $)$ than for men ( $8 \mathrm{mg}$ /day) [179]. This may lead more athletic women to supplement with iron to enhance health and/or performance. Consumption of iron supplements was associated with a lower prevalence of iron deficiency among adult women in a US national survey [180]. Protein and creatine were also taken by a larger proportion of men than women, possibly because of differences in rationales for using dietary supplements. When men and women were queried separately on their reasons for using dietary supplements within the same study, men reported the development of strength and/or muscle mass as a higher priority than did 
Table 5 Summary data on dietary supplement use in US national surveys

\begin{tabular}{|c|c|c|c|c|c|c|c|c|c|c|}
\hline \multirow[t]{3}{*}{ Survey } & \multirow[t]{3}{*}{ Study } & \multirow{3}{*}{$\begin{array}{l}\text { Survey } \\
\text { year(s) }\end{array}$} & \multirow[t]{3}{*}{$n$} & \multirow{3}{*}{$\begin{array}{l}\text { Reporting } \\
\text { timeframe }\end{array}$} & \multicolumn{6}{|c|}{ Prevalence $(\%)$} \\
\hline & & & & & \multicolumn{2}{|c|}{ Any VM } & \multicolumn{2}{|c|}{ MVM } & \multicolumn{2}{|c|}{ Vitamin C } \\
\hline & & & & & M & $\mathrm{W}$ & M & W & M & $\mathrm{W}$ \\
\hline \multirow{3}{*}{$\begin{array}{l}\text { National Health } \\
\text { Interview } \\
\text { Survey (NHIS) }\end{array}$} & Subar and Block 1990 [183] & 1987 & $9160 \mathrm{M}, 12,920 \mathrm{~F}$ & Daily use & 19 & 27 & 15 & 20 & 7 & 8 \\
\hline & Slesinski et al. 1995 [184] & 1992 & $5120 \mathrm{M}, 6885 \mathrm{~F}$ & Daily use & 20 & 27 & 17 & 22 & 7 & 8 \\
\hline & Millens et al. 2004 [185] & 2000 & $34,085 \mathrm{M}$ and $\mathrm{F}$ & Daily use & 29 & 39 & 24 & 33 & 10 & 12 \\
\hline \multirow{4}{*}{$\begin{array}{l}\text { National Health } \\
\text { and Nutrition } \\
\text { Survey (NHANES) }\end{array}$} & Koplan et al. 1986 [186] & $1976-1980$ & $5915 \mathrm{M}, 6588 \mathrm{~F}$ & Use $\geq 1$ time/wk & 30 & 40 & ND & ND & ND & ND \\
\hline & Balluz et al. 2000 [187] & 1988-1994 & $33,905 \mathrm{M}$ and $\mathrm{F}$ & Use in last month & 35 & 44 & ND & ND & ND & ND \\
\hline & Radimer et al. 2004 [188] & 1999-2000 & $2260 \mathrm{M}, 2602 \mathrm{~F}$ & Use in last month & 46 & 57 & 32 & 38 & 12 & 13 \\
\hline & Kennedy et al. 2013 [189] & $2007-2008$ & $3364 \mathrm{M}$ and $\mathrm{F}$ & Use in last month & 42 & 54 & ND & ND & ND & ND \\
\hline
\end{tabular}

$V M$ vitamin and/or mineral, $M V M$ multivitamin/multimineral, $M$ males, $F$ females, $N D$ no data, $w k$ week

women $[7,11,19]$. Protein and creatine supplementation have both been demonstrated to increase strength and lean body mass [181, 182].

Table 5 shows summary data from the National Health Interview Surveys (NHIS) [183-185] and the National Health and Nutrition Surveys (NHANES) [186-189], both of which are nationally representative samples of the general US population. Both surveys observed a secular (temporal) trend, indicating that dietary supplement use has been increasing over time, although the most recent NHANES data suggested a leveling off in use [188, 189]. The increase in dietary supplement use is in consonance with data showing an eightfold increase in commercial dietary supplement sales from 1994 to 2012 [3, 4]. In the present review, studies were compiled by publication date in an attempt to determine whether a temporal trend was present, but no such trend could be discerned. Even the earliest studies in the literature demonstrated that a very large proportion of athletes were using dietary supplements [54, 56, 83, 95, 139, 147].

Additionally, Table 5 includes summary data on multivitamins/multiminerals and vitamin $\mathrm{C}$, mostly from the NHIS [183-185], but including one NHANES survey [188]. There are some limitations in comparing these national survey data with those of the athletes. The NHIS survey asked individuals about daily use of supplements, and the NHANES asked about use in the last month. In the meta-analyses of athletes presented here (Tables 2, 3, 4) the reporting timeframe included 'current', 'usual', or 'regular' use. The athlete data were also collected over a much greater range of years than the NHIS/NHANES data, and the temporal trends differed, as noted above. Despite these limitations, a comparison of the data suggested that prevalence of use of any vitamins/minerals and multivitamins/multiminerals was somewhat higher, and that of vitamin $\mathrm{C}$ much higher among athletes than the general US population. Similar to the athlete data, a recent systematic review showed that the prevalence of multivitamin/multimineral and vitamin $\mathrm{C}$ use was higher in the military than in civilian samples [190]. Military and athletic groups may be more likely to use dietary supplements because of a greater concern with health and performance $[10,35,53$, 149, 191-196]. For example, consider protein supplements. Protein supplementation in combination with resistance training augments gains in fat-free mass [182]. National surveys in the USA indicate that only $1 \%$ of the general population uses amino acid supplements [197]. In contrast, the athlete data suggests a much larger prevalence of use (Table 4), as does the more limited military data [190].

Use of herbal supplements could be high in some athletic subgroups, especially among elite athletes. For example, use of ginseng ranged from 16 to $51 \%$ in a study of Korean Olympic athletes [144, 153] and $27 \%$ in a study of Saudi Arabian professional soccer players [68]. Echinacea was used by $60 \%$ of professional surfers [123], $39 \%$ of elite Australian swimmers [58], and 28 and $44 \%$ of elite male and female, respectively, figure skaters [15]. Nonetheless, in most groups of athletes, $10 \%$ or fewer used herbal supplements $[10,19,23,49,67,80,101,121$, $128,159,198]$. In US national surveys, the most commonly used herbal supplements were Echinacea, garlic, Ginkgo biloba, ginseng, and Saint John's Wort, with most use prevalences well below $5 \%$ [185, 197, 199]. Since the studies reviewed here were conducted over a long period of time, the popularity of different supplements may have changed over time as they have in the general US population [199, 200].

We suspected there would be differences among studies based on nationality because of cultural and/or socioeconomic conditions. Some differences were noted in the use of ginseng, since Korean and Saudi Arabian athletes had a higher prevalence of use of this herbal supplement [68, $144,153]$ than other nationalities $[9-12,15,19,49,58,80$, 131, 132, 141, 149, 152, 159, 198]. However, no other 
major differences were noted; there was a wide range of dietary supplement usages regardless of nationality.

\section{Suggestions for Improving Research on Dietary Supplement Use in Athletes}

Because of the lack of homogeneity in dietary supplement use prevalences among athletes, the most appropriate way to conclude this review is to offer suggestions for improving the collection of dietary supplement data. Future studies on athletes and other groups should consider five major issues. First, the definition of dietary supplement should be clearly stated. The legal definition provided by the DSHEA of 1994 [2] can serve as a standard. Second, studies should be specific about the types of dietary supplements used by study participants. Reporting in general categories like 'antioxidant', 'energy', 'herbal', 'bodybuilding', and the like may be useful for some purposes but does not provide the specificity needed for comparisons across studies or the identification of the specific dietary supplements that are being used by athletes. Third, the reporting timeframe should be specific and include several periods. The most useful reporting timeframes appear to be daily, 2-6 times/week, 1 time/week, and $<1$ time/week. Fourth, the response rate (those volunteering/those solicited) should be specified and, if possible, characteristics of respondents and non-respondents described so that possible bias can be assessed. Finally, studies are needed that use the same experimental methods to compare dietary supplement use across a wide variety of sports so sport-specific differences and temporal trends can be established. Following these guidelines will assist in providing more accurate and comparable data on dietary supplement use in specific athletic populations.

\section{Conclusions}

When dietary supplement use was compiled by sport, elite versus non-elite athletic status, and supplement type, there was high variability in use prevalence among studies. Elite athletes appeared to use dietary supplements much more than their non-elite counterparts. For most dietary supplements, use prevalence appeared similar for men and women, with the exception of iron, creatine, protein, and vitamin E. Suggested improvements in future studies include (1) defining dietary supplements in surveys and dietary evaluations; (2) querying for very specific dietary supplements; (3) using a variety of reporting timeframes (e.g., daily, 2-6 times/week, 1 time/week and $<1$ time/ week); (4) reporting the sampling frame, number of individuals solicited, and number responding; (5) reporting characteristics of volunteers (and non-volunteers, if available); and (6) using similar methods on several occasions to examine possible temporal trends among athletes.

\section{Compliance with Ethical Standards}

This research was supported in part by an appointment to the Knowledge Preservation Program at the US Army Research Institute of Environmental Medicine (USARIEM) and the US Army Public Health Center (APHC) administered by the Oak Ridge Institute for Science and Education through an interagency agreement between the US Department of Energy and USARIEM. Funding was also provided by the Center Alliance for Nutrition and Dietary Supplement Research. Joseph Knapik, Ryan Steelman, Sally Hoedebecke, Krista Austin, Emily Farina and Harris Lieberman declare that they have no conflict of interest with the content of this review.

Open Access This article is distributed under the terms of the Creative Commons Attribution 4.0 International License (http:// creativecommons.org/licenses/by/4.0/), which permits unrestricted use, distribution, and reproduction in any medium, provided you give appropriate credit to the original author(s) and the source, provide a link to the Creative Commons license, and indicate if changes were made.

\section{References}

1. National Institute of Health. Strengthening knowledge and understanding of dietary supplements. 2013. Available from: http://ods.od.nih.gov/About/DSHEA_Wording.aspx. Cited 4 Feb 2013.

2. Federal Drug Administration. Dietary Supplement Health and Education Act of 1994. 1994. Available from: http://www.fda. gov/RegulatoryInformation/Legislation/FederalFoodDrugand CosmeticActFDCAct/SignificantAmendmentstotheFDCAct/ ucm148003.htm. Cited 11 Mar 2013.

3. Saldanha LG. The dietary supplement marketplace. Constantly evolving. Nutr Today. 2007;42(2):52-4.

4. Infographics: highlights from the 2013 Supplement Business Report. Nutr Bus J. 2013. http://newhope360.com/supplements/ infographic-highlights-2013-supplement-business-report. Accessed 23 Aug 2014.

5. Nutrition Business Journal Global Supplement and Nutrition Industry Report 2014. Nutr Bus J. 2014. http://newhope360.com/ site-files/newhope360.com/files/uploads/2014/Global_Report\% 20summary.pdf. Accessed 23 Aug 2014.

6. Brill JB, Keane MW. Supplementation patterns of competitive male and female bodybuilders. Int $\mathrm{J}$ Sport Nutr. 1994;4:398-412.

7. Krumbach CJ, Ellis DR, Driskell JA. A report on vitamin and mineral supplement use among university athletes in a division I institution. Int J Sport Nutr. 1999;9:416-25.

8. Swirzinski L, Latin RW, Berg K, et al. A survey of sports nutrition supplements in high school football players. J Strength Cond Res. 2000;14(4):464-9.

9. Sundgot-Borgen J, Berglund B, Torstveit MK. Nutritional supplements in Norwegian elite athletes-impact of international ranking and advisors. Scand J Med Sci Sports. 2003;13:138-44.

10. Morrison LJ, Gizin F, Shorter B. Prevalent use of dietary supplements among people who exercise at a commercial gym. Int J Sports Nutr Exerc Metabol. 2004;14:481-92.

11. Froiland K, Koszewski W, Hingst J, et al. Nutrition supplement use among college athletes and their sources of information. Int J Sports Nutr Exerc Metabol. 2004;14:104-20. 
12. Petroczi A, Naughton DP, Mazanov J, et al. Performance enhancement with supplements: incongruence between rationale and practice. J Int Soc Sports Nutr. 2007;4:19.

13. Kim J, Chun YS, Kang SK, et al. The use of herbal/traditional products supplementation and doping tests in elite athletes. Int $\mathrm{J}$ Appl Sports Sci. 2010;22(2):137-49.

14. Sousa M, Fernandes MJ, Moreira P, et al. Nutritional supplement usage by Portuguese athletes. Int $\mathrm{J}$ Vit Nutr Res. 2013;83(1):48-58.

15. Ziegler PJ, Nelson JA, Jonnalagadda SS. Use of dietary supplements by elite figure skaters. Int J Sports Nutr Exerc Metabol. 2003;13:266-76.

16. Nieper A. Nutritional supplement practices in UK junior national track and field athletes. $\mathrm{Br} \mathrm{J}$ Sports Med. 2005;39:645-9.

17. Goston JL, Correia MITD. Intake of nutritional supplements among people exercising in gyms and influencing factors. Nutrition. 2010;26:604-11.

18. Dascombe DJ, Karunaratna M, Cartoon J, et al. Nutritional supplementation habits and perceptions of elite athletes within a state-based sporting institute. J Med Sci Sports. 2010;13:274-80.

19. Lun V, Erdman KA, Fung TS, et al. Dietary supplementation practices in Canadian high-performance athletes. Int J Sports Nutr Exerc Metabol. 2012;22:31-7.

20. Bailey RL, Gahche JJ, Miller PE, et al. Why US adults use dietary supplements. JAMA Int Med. 2013;173(3):355-61.

21. Dickinson A, Bonci L, Boyon N, et al. Dietitians use and recommend dietary supplements: report of a survey. Nutr J. 2012;11:14.

22. Huang HY, Caballero B, Chang S, et al. The efficacy and safety of multivitamin and mineral supplement use to prevent cancer and chronic disease in adults: a systematic review for a National Institute of Health State-of-the-Science Conference. Ann Int Med. 2006;145:372-85.

23. Lazic JS, Dikic N, Radivojevic N, et al. Dietary supplements and medications in elite sport-polypharmacy or real need? Scand J Med Sci Sports. 2011;21:260-7.

24. Outram S, Stewart B. Doping through supplement use: a review of available empirical data. Int J Sports Nutr Exerc Metabol. 2015;25(1):54-9.

25. Petroczi A, Taylor G, Naughton DP. Mission impossible? Regulatory and enforcement issures to ensure safety of dietary supplements. Food Chem Toxicol. 2011;49(2):393-402.

26. Sobal J, Marquart LF. Vitamin/mineral supplement use among athletes: a review of the literature. Int $\mathrm{J}$ Sports Nutr. 1994;4:320-34.

27. Moher D, Liberati A, Tetzlaff J, et al. Preferred reporting items for systematic reviews and meta-analyses: the PRISMA statement. PLoS Med. 2009;6(7):e1000097.

28. Loney PL, Chambers LW, Bennett KJ, et al. Critical appraisal of health research literature: prevalence or incidence of a health problem. Chronic Dis Can. 2000;19(4):170-6.

29. Huedo-Medina T, Sanchez-Meca J, Marin-Martinez F, et al. Assessing heterogeneity in meta-analysis: $Q$-statistic or $I^{2}$ index? Psychol Methods. 2006;11(2):193-206.

30. Higgins JPT, Thompson SG, Deeks JJ, et al. Measuring inconsistency in meta-analysis. Br Med J. 2003;327:557-60.

31. Duval S, Tweedie R. Trim and Fill: a simple funnel-plot-based method of testing and adjusting for publication bias in metaanalysis. Biometrics. 2000;56(2):455-63.

32. Heikkinen A, Alaranta A, Helenius I, et al. Use of dietary supplements in Olympic athletes is decreasing: a follow-up study between 2002 and 2009. J Int Soc Sports Nutr. 2011;8:1.
33. Heikkinen A, Alaranta A, Helenius I, et al. Dietary supplement habits and perceptions of dietary supplement use among elite Finnish athletes. Int J Sport Nutr Exerc Metab. 2011;21:271-9.

34. Erdman KA, Fung TS, Reimer RA. Influence of performance level on dietary supplementation in elite Canadian athletes. Med Sci Sports Exerc. 2006;38(2):349-56.

35. Erdman KA, Fung TS, Doyle-Baker PK, et al. Dietary supplementation of high-performance Canadian athletes by age and gender. Clin J Sport Med. 2007;17(6):458-64.

36. Deuster PA, Kyle SB, Moser PB, et al. Nutritional survey of highly trained women runners. Am J Clin Nutr. 1986;44:954-62.

37. Deuster PA, Kyle SB, Moser PB, et al. Nutritional intakes and status of highly trained amenorrheic and eumenorrheic women runners. Fertil Steril. 1986;46(4):636-43.

38. Singh A, Deuster PA, Moser PB. Zinc and copper status of women by physical activity and menstrual status. J Sports Med Phy Fitness. 1990;30(1):29-36.

39. Petroczi A, Naughton DP. The age-gender-status profile of high performing athletes in the UK taking nutritional supplements: lessons for the future. J Int Soc Sports Nutr. 2008;5:2.

40. Petroczi A, Naughton D, Mazanov J, et al. Limited agreement exists between rationale and practice in athletes' supplement use for maintenance of health: a retrospective study. Nutr Res. 2007;6:34.

41. Mazanov J, Petroczi A, Bingham J, et al. Towards an empirical model of performance enhancing supplement use: a pilot study among high performance UK athletes. J Sci Med Sport. 2008;11:185-90.

42. Short SH, Short WR. Four-year study of university athletes' dietary intake. J Am Diet Assoc. 1983;82(6):632-45.

43. Jacobson BH, Aldana SG. Current nutrition practices and knowledge of varsity athletes. J Appl Sport Sci Res. 1992;6(4):232-8.

44. Sobal J, Marquat LF. Vitamin/mineral supplement use among high school athletes. Adolescence. 1994;29(116):835-45.

45. LaBotz M, Smith BW. Creatine supplement use in an NCAA Division I athletic program. Clin J Sport Med. 1999;9:167-9.

46. Greenwood M, Ferris J, Kreider R, et al. Creatine supplementation patterns and perceived effects in select Division I collegiate athletes. Clin J Sport Med. 2000;10:191-4.

47. Smith J, Dahm DL. Creatine use among a selected population of high school athletes. Mayo Clin Proc. 2000;75:1257-63.

48. Metzl JD, Small E, Levine SR, et al. Creatine use among young athletes. Pediatrics. 2001;108(2):421-5.

49. Mason MA, Giza M, Clayton L, et al. Use of nutritional supplements by high school football and volleyball players. Iowa Orthop J. 2001;21:43-8.

50. Jonnalagadda SS, Rosenbloom CA, Skinner R. Dietary practices, attitudes, and physiological status of collegiate freshman football players. J Strength Cond Res. 2001;15(4):507-13.

51. Cole CR, Salvaterra GF, Davis JE, et al. Evaluation of dietary practices of National Collegiate Athletic Association Division I football players. J Strength Cond Res. 2005;19(3):490-4.

52. Scofield DE, Unruh S. Dietary supplement use among adolescent athletes in Central Nebraska and their sources of information. J Strength Cond Res. 2006;20(2):452-5.

53. Duellman MC, Lukaszuk JM, Prawitz AD, et al. Protein supplement users among high school athletes have misconceptions about effectiveness. J Strength Cond Res. 2008;22:1124-9.

54. Houston ME. Diet, training and sleep: a survey study of elite Canadian swimmers. Can J Appl Sport Sci. 1980;5:161-3.

55. Adams MM, Porcello LP, Vivian VM. Effect of a supplement on dietary intakes of female collegiate swimmers. Physician Sports Med. 1982;10(7):122-34. 
56. Campbell ML, MacFadyen KL. Nutrition knowledge. Beliefs and dietary practices of competitive swimmers. Can Home Econ J. 1984;34(1):47-51.

57. Hawley JA, Williams MM. Dietary intake of age-group swimmers. Br J Sports Med. 1991;25(3):154-8.

58. Baylis A, Cameron-Smith D, Burke LM. Inadvertent doping through supplement use by athletes: assessment and management of the risk in Australia. Int $\mathrm{J}$ Sport Nutr Exerc Metab. 2001;11:365-83.

59. Paschoal VCP, Amancio OMS. Nutritional status of Brazilian elite swimmers. Int J Sport Nutr Exerc Metab. 2004;14:81-94.

60. Slattery KM, Coutts AJ, Wallace LK. Nutritional practices of elite swimmers during an intensified training camp: with particular reference to antioxidants. J Sports Med Phy Fitness. 2012;52:501-5

61. Sajber D, Rodek J, Escalante Y, et al. Sports nutrition and doping factors in swimming: parallel analysis among athletes and coaches. Coll Anthropol. 2013;37(2):179-86.

62. Burke LM, Read RSD. A study of dietary patterns of elite Australian football players. Can J Sports Sci. 1988;13:15-9.

63. Burke LM, Gollan RA, Read RSD. Dietary intake and food use of groups of elite Australian male athletes. Int J Sports Nutr. 1991;1:378-94.

64. Ama PFM, Betnga B, Moor VJA, et al. Football and doping: a study of African amateur footballers. Br J Sports Med. 2003;37:307-10.

65. Waddington I, Malcolm D, Roderick M, et al. Drug use in English professional football. Br J Sports Med. 2005;39:e18.

66. Tscholl P, Junge A, Dvorak J. The use of medication and nutritional supplements during FIFA World Cups 2002 and 2006. Br J Sports Med. 2008;42:725-30.

67. Russell M, Pennock A. Dietary analysis of young professional soccer players for 1 week during the competitive season. J Strength Cond Res. 2011;25(7):1816-23.

68. Aljaloud SO, Ibrahim SA. Use of dietary supplements among professional athletes in Saudi Arabia. J Nutr Metab. 2013;2013:1-7.

69. Faber M, Benade AJS. Nutrient intake and dietary supplementation in body-builders. S Afr Med J. 1987;72:831-4.

70. Sandoval WM, Heyward VH, Lyons TM. Comparison of body composition, exercise and nutritional profiles of female and male body builders at competition. J Sports Med Phys Fitness. 1989;29(1):63-70.

71. Heyward VH, Sandoval WM, Colville BC. Anthropometric, body composition and nutritional profiles of bodybuilders during training. J Appl Sports Sci Res. 1989;3(2):22-9.

72. Lamar-Hildebrand N, Saldanha L, Enders J. Dietary and exercise practices of college-aged female body builders. J Am Diet Assoc. 1989;89(9):1308-10.

73. Kleiner SM, Bazzarre TL, Litchford MD. Metabolic profiles, diet, and health practices of championship male and female bodybuilders. J Am Diet Assoc. 1990;90(7):962-7.

74. Linseisen J, Metges CC, Wolfram G. Dietary habits and serum lipids of a group of German amateur bodybuilders. Eur J Nutr. 1993;32(4):289-300.

75. Walberg-Rankin J, Edmonds CE, Gwazdauskas FC. Diet and weight changes in female bodybuilders before and after competition. Int J Sports Nutr. 1993;3:87-102.

76. Andersen RE, Barlett SJ, Morgan GD, et al. Weight loss, psychological, and nutritional patterns in competitive male body builders. Int J Eat Disord. 1995;18(1):49-57.

77. Karimian J, Esfahani PS. Supplement consumption in body builder athletes. J Res Med Sci. 2011;16(10):1347-53.

78. Nowak RK, Knudsen KS, Schulz LO. Body composition and nutrient intakes of college men and women basketball players. J Am Diet Assoc. 1988;88:575-8.
79. Schulz LO. Factors influencing the use of nutritional supplements by college students with varying levels of physical activity. Nutr Res. 1988;8:459-66.

80. Schroder H, Navarro E, Mora J, et al. The type, amount, frequency and timing of dietary supplement use by elite players in the first Spanish Basketball League. J Sports Sci. 2002;20:353-8.

81. Beals KA. Eating behaviors, nutritional status, and menstrual function in elite female adolescent volleyball players. J Am Diet Assoc. 2002;102(9):1293-6.

82. Oppliger RA, Landry GL, Foster SW, et al. Bulimic knowledge among interscholastic wrestlers: a statewide survey. Pediatrics. 1993;91(4):826-31.

83. Bright-See E, Croy J, Brayshaw J, et al. Nutrition briefs and practices of ballet students. J Can Diet Assoc. 1978;39(4):324-31.

84. Calabrese LH, Kirkendall DT, Floyd M, et al. Menstrual abnormalities, nutritional patterns and body composition in female classic ballet dancers. Physician Sports Med. 1983;11(2):86-98.

85. Cohen JL, Potosnak L, Frank O, et al. A nutritional and hematological assessment of elite ballet dancers. Physician Sports Med. 1985;13(5):43-54.

86. Braisted JR, Mellin L, Gong EJ, et al. The adolescent ballet dancer. Nutritional practices and characteristics associated with anorexia nervosa. J Adolesc Health Care. 1985;6:365-71.

87. Benson J, Gillien DM, Bourdet K, et al. Inadequate nutrition and chronic caloric restriction in adolescent ballerinas. Physician Sports Med. 1985;13(10):79-90.

88. Frusztajer NT, Dhuper S, Warren MP, et al. Nutrition and the incidence of stress fractures in ballet dancers. Am J Clin Nutr. 1990;51:779-83.

89. Zenic N, Peric M, Zubcevic NG, et al. Comparative analysis of substance use in ballet, dance sport, and synchronized swimming. Med Probl Perform Art. 2010;25:75-81.

90. Moffatt RJ. Dietary status of elite female high school gymnasts: inadequacy of vitamin and mineral intake. J Am Diet Assoc. 1984;84:1361-4.

91. Loosli AR, Benson J, Gillien DM, et al. Nutrition habits and knowledge in competitive adolescent female gymnasts. Physician Sports Med. 1986;14(6):118-30.

92. Ersoy G. Dietary status and anthropometric assessment of child gymnasts. J Sports Med Phy Fitness. 1991;31(4):577-80.

93. Jonnalagadda SS, Benardot D, Nelson M. Energy and nutrient intakes of the United States National Woman's Artistic Gymnastic Team. Int J Sport Nutr. 1998;8:331-44.

94. Lampe JW, Salvin JL, Apple FS. Poor iron status of women runners training for a marathon. Int J Sports Med. 1986;7:111-4.

95. Barr SI. Nutrition knowledge and selected nutritional practices of female recreational athletes. J Nutr Educ. 1986;18:167-74.

96. Thibault G, Lambert J, Rivard M, et al. Utilization of ergogenic aids and the attitudes toward safety in marathon runners. In: Katch FI, editor. The 1984 Olympic Scientific Congress proceedings, volume 2 Sports, Health and Nutrition. Champaign: Human Kinetics Publishers Inc; 1986.

97. Nieman DC, Gates JR, Butler JV, et al. Supplementation patterns in marathon runners. J Am Diet Assoc. 1989;89:1615-9.

98. Khoo CS, Rawson NE, Robinson ML, et al. Nutrient intake and eating habits of triathletes. Ann Sports Med. 1987;3: 144-50.

99. Worme JD, Doubt TJ, Singh A, et al. Dietary patterns, gastrointestinal complaints, and nutrition knowledge of recreational athletes. Am J Clin Nutr. 1990;51:690-7.

100. Nogueira JAD, DeCosta THM. Nutrient intake and eating habits of triathletes on a Brazilian diet. Int J Sport Nutr Exerc Metab. 2004;14:684-97. 
101. Knez WL, Peake JM. The prevalence of vitamin supplementation in ultraendurance triathletes. Int J Sport Nutr Exerc Metab. 2010;20:507-14.

102. Dolan SH, Houston M, Martin SB. Survey results of the training, nutrition, and mental preparation of triathletes: practical implications of findings. J Sports Sci. 2011;29(10):1019-28.

103. Evers CL. Dietary intake and symptoms of anorexia nervosa in female university dancers. J Am Diet Assoc. 1987;87(1):66-8.

104. Frederick L, Hawkins ST. A comparison of nutrition knowledge and attitudes, dietary practices, and bone densities of postmenopausal women, female college athletes, and nonathletic college women. J Am Diet Assoc. 1992;92:299-305.

105. Sekulic D, Kostic R, Miletic D. Substance use in dance sports. Med Probl Perform Art. 2008;23(2):66-71.

106. Singh A, Evans P, Gallagher KL, et al. Dietary intake and biochemical profiles of nutritional status of untramarathoners. Med Sci Sports Exerc. 1993;25(3):328-34.

107. Peters EM, Goetzsche JM. Dietary practices of South African ultradistance runners. Int J Sports Nutr. 1997;7:80-103.

108. Knechtle B, Knechtle P, Schulze I, et al. Vitamin, mineral and race performance in ultra-endurance runners-Deutschlandlauf 2006. Asia Pac J Clin Nutr. 2008;17(2):194-8.

109. Hoffman MD, Fogard K. Demographic characteristics of 161-km ultramarathon runners. Res Sports Med. 2012;20:59-69.

110. Clark N, Nelson M, Evans W. Nutrition education for elite female runners. Physician Sports Med. 1988;16(2):124-36.

111. Pate RR, Sargent RG, Baldwin C, et al. Dietary intake of women runners. Int J Sports Med. 1990;11:461-6.

112. Beis LY, Willkomm L, Ross R, et al. Food and micronutrient intake of elite Ethiopian distance runners. J Int Soc Sports Nutr. 2011;8:7.

113. Ziegler PJ, Khoo CS, Kris-Etherton PM, et al. Nutritional status of nationally ranked junior US figure skaters. J Am Diet Assoc. 1998;98(7):809-11.

114. Ziegler P, Sharp R, Hughes V, et al. Nutritional status of teenage female competitive figure skaters. J Am Diet Assoc. 2002;101:374-9.

115. Rosen O, Sundgot-Borgen J, Maehlum S. Supplement use and nutritional habits in Norwegian elite athletes. Scand J Med Sci Sports. 1999;9:28-35.

116. Bobb A, Pringle D, Ryan AJ. A brief study of the diet of athletes. J Sports Med. 1969;9:255-62.

117. Bents RT, Marsh E. Patterns of ephedra and other stimulant use in collegiate hockey athletes. Int J Sport Nutr Exerc Metab. 2006;16:636-43.

118. Soper J, Carpenter RA, Shannon BM. Nutrition knowledge of aerobic dance instructors. J Nutr Educ. 1992;24:59-66.

119. Slavin JL, McNamara EA, Lutter JM. Nutritional practices of women cyclists, including recreational riders and elite riders. In: Katch FI, editor. Sports, health and nutrition. The 1984 Olympic Scientific Congress proceedings, volume 2. Champaign: Human Kinetics Publishers, Inc; 1986. p. 107-11.

120. Walsh M, Cartwright L, Corish C, et al. The body composition, nutritional knowledge, attitudes, behaviors and future educational needs of senior schoolboy rugby players in Ireland. Int $\mathbf{J}$ Sports Nutr Exerc Metabol. 2011;21:365-76.

121. Rodek J, Sekulic D, Kondric M. Dietary supplementation and doping-related factors in high-level sailing. J Int Soc Sports Nutr. 2012;9:51.

122. Snyder AC, Schulz LO, Foster C. Voluntary consumption of a carbohydrate supplement by elite speed skaters. J Am Diet Assoc. 1989;89(8):1125-7.

123. Felder JM, Burke LM, Lowden BJ, et al. Nutritional practices of elite female surfers during training and competition. Int J Sport Nutr. 1998;8:36-8.
124. Kondric M, Sekulic D, Mandic GF. Substance use and misuse among Slovenian table tennis players. Subst Use Misuse. 2010;45:543-53.

125. Faber M, Benade AJS. Mineral and vitamin intake in field athletes (discus-, hammer-, javelin-throwers and shotputters). Int J Sports Med. 1991;12:324-7.

126. Mullins VA, Houtkooper LB, Howell WH, et al. Nutritional status of US elite female heptathletes during training. Int J Sport Nutr Exerc Metab. 2001;11:299-314.

127. Grandjean AC. Vitamin, diet, and the athlete. Clin Sports Med. 1983;2(1):105-14.

128. Grandjean AC, editor. Profile on nutrition beliefs and practices of the elite athlete. Human Kinetics: Champaign; 1985.

129. Fogelholm CM, Himberg JJ, Alopaeus K, et al. Dietary and biochemical indices of nutritional status in male athletes and controls. J Am Coll Nutr. 1992;11(2):181-91.

130. Musaiger AO. Dietary habits of athletes in Bahrain. Nutr Health. 1994;10:17-25.

131. Slater G, Tan B, Teh KC. Dietary supplement practices of Singaporean athletes. Int $\mathbf{J}$ Sport Nutr Exerc Metab. 2003; 13:320-32.

132. Petroczi A, Naughton DP, Pearce G, et al. Nutritional supplement use by elite young UK athletes: fallacies of advice regarding efficacy. J Int Soc Sports Nutr. 2008;5:22.

133. Lun V, Erdman KA, Reimer RA. Evaluation of nutritional intake in Canadian high-performance athletes. Clin J Sport Med. 2009; 19:405-11.

134. Braun H, Koehler K, Geyer H, et al. Dietary supplement use among elite young German athletes. Int J Sport Nutr Exerc Metab. 2009;19:97-109.

135. Tscholl P, Alonso JM, Dolle G, et al. The use of drugs and nutritional supplements in top-level track and field athletes. Am J Sports Med. 2010;38(1):133-40.

136. deSilva A, Samarasinghe Y, Senanayake D, et al. Dietary supplement intake in national level Sri Lankan athletes. Int J Sports Nutr Exerc Metabol. 2010;20:15-20.

137. Nazni P, Vimala S. Nutrition knowledge, attitude and practice of college sportsman. Asian J Sports Med. 2010;1(2):93-100.

138. Sato A, Kamei A, Kamihigashi E, et al. Use of supplements by young elite Japanese athletes participating in the 2010 Youth Olympic games in Singapore. Clin Sports Med. 2012;22(5):418-23.

139. Steel JE. A nutritional study of Australian Olympic athletes. Med J Aust. 1970;2:119-23.

140. Barry A, Cantwell T, Doherty F, et al. A nutritional survey of Irish athletes. Br J Sports Med. 1981;15:99-109.

141. Berglund B. Sports medicine update. Scand J Med Sci Sports. 2001;11:369-71.

142. Corrigan B, Kazlauskas R. Medication use in athletes selected for doping control at the Sydney Olympics (2000). Clin J Sport Med. 2003;13:33-40.

143. Tsitsimpikou C, Tsiokanos A, Tsarouhas K, et al. Medication use by athletes at the Athens 2004 summer Olympic Games. Clin J Sport Med. 2009;19(1):33-8.

144. Kim J, Kang SK, Jung HS, et al. Dietary supplementation patterns of Korean Olympic athletes participating in the Beijing 2008 summer Olympic Games. Int J Sports Nutr Exerc Metabol. 2011;8:166-74.

145. Diehl K, Thiel A, Zipfel S, et al. Elite adolescent athlete's use of dietary supplements: characteristics, opinions, and sources of information. Int J Sports Nutr Exerc Metabol. 2012;22:165-74.

146. Werblow JA, Fox HM, Henneman A. Nutritional knowledge, attitudes, and food patterns of women athletes. J Am Diet Assoc. 1978;73:212-5.

147. Barr SI. Nutritional knowledge of female varsity athletes and university students. J Am Diet Assoc. 1987;87(12):1660-4. 
148. Jacobson BH, Sobonya C, Ransone J. Nutrition practices and knowledge of college varsity athletes. J Strength Cond Res. 2001;15(1):63-8.

149. Herbold NH, Visconti BK, Frates S, et al. Traditional and nontraditional supplement use by collegiate female varsity athletes. Int J Sports Nutr Exerc Metabol. 2004;14:586-93.

150. Burns RD, Schiller R, Merrick MA, et al. Intercollegiate student athlete use of nutritional supplements and the role of athletic trainers and dietitians in nutritional counseling. J Am Diet Assoc. 2004;104:246-9.

151. Kristiansen M, Levy-Milne R, Barr S, et al. Dietary supplement use by varsity athletes at a Canadian university. Int J Sports Nutr Exerc Metabol. 2005;15:195-210.

152. Tian HH, Ong WS, Tan CL. Nutrition supplement use among university athletes in Singapore. Singap Med J. 2009;50(2):165-72.

153. Kim J, Lee N, Kim EJ, et al. Anti-doping education and dietary supplementation practice in Korean elite university athletes. Nutr Res Pract. 2011;5(4):349-56.

154. Buxton C, Hagan JE. A survey of energy drink consumption practices among student-athletes in Ghana: lessons for developing health education intervention progrmmes. J Int Soc Sports Nutr. 2012;9:9.

155. Hoyte CO, Albert D, Heard KJ. The use of energy drinks, dietary supplements, and prescription medication by United States college students to enhance athletic performance. J Community Health. 2013;38(3):575-80.

156. Darvishi L, Askari G, Hariri M, et al. The use of nutritional supplements among male collegiate athletes. Int J Prev Med. 2013;9(Suppl 1):S68-72.

157. Douglas PD, Douglas JG. Nutrition knowledge and food practices of high school athletes. $J$ Am Diet Assoc. 1984;84(10):1198-202.

158. Krowchuk DP, Anglin TM, Goodfellow DB, et al. High school athletes and the use of ergogenic aids. Am J Dis Child. 1989;143:486-9.

159. Massad SJ, Shier NW, Koceja DM, et al. High school athletes and nutritional supplements: a study of knowledge and use. Int J Sports Nutr. 1995;5(3):232-45.

160. Kim SH, Keen CL. Patterns of vitamin/mineral supplement usage by adolescents attending athletic high school in Korea. Int J Sport Nutr. 1999;9:391-405.

161. Ray TR, Eck JC, Covington LA, et al. Use of oral creatine as an ergogenic aid for increased sports performance: perception of adolescent athletes. South Med J. 2001;94(6):608-62.

162. Bartee RT, Grandjean B, Dunn MS, et al. Predictors of dietary supplement use among adolescent athletes. Pediatr Exerc Sci. 2004;16:250-64.

163. Sheppard HL, Raichada SM, Kouri KM, et al. Use of creatine and other supplements by members of civilian and military health clubs: a cross-sectional survey. Int J Sport Nutr Exerc Metab. 2000;10:245-59.

164. Kanayama G, Gruber AJ, Pope HG, et al. Over-the-counter drug use in gymnasiums: an underrecognized substance abuse problem? Psychother Psychosom. 2001;70:137-40.

165. Chlopicka J, Wandas P, Zachwieja Z. Dietary supplements selected by young people exercising in fitness rooms in Krakow and environs. Roczn PZH. 2007;58(1):185-9.

166. Sanchez-Oliver A, Miranda-Leon MT, Guerra-Hernandez E. Prevalence of protein supplement use at gyms. Nutr Hosp. 2011;26(5):1168-74.

167. Tsitsimpikou C, Chrisostomou N, Papalexis $P$, et al. The use of nutritional supplements among recreational athletes in Athens, Greece. Int J Sport Nutr Exerc Metab. 2011;21:377-84.

168. Bianco A, Mammina C, Paoli A, et al. Protein supplementation in strength and conditioning adepts: knowledge, dietary behavior and practices in Palermo, Italy. J Int Soc Sports Nutr. 2011;8:25.

169. Bianco A, Mammina C, Thomas E, et al. Protein supplementation and dietary behaviors or resistance trained men and women attending commercial gyms: a comparison study between the city center and suburbs of Palermo, Italy. J Int Soc Sports Nutr. 2014;11:30.

170. Parr RB, Porter MA, Hodgson SC. Nutrition knowledge and practice of coaches, trainers and athletes. Physician Sports Med. 1984;12(3):127-36.

171. Bazzarre TL, Scarpino A, Sigmon R, et al. Vitamin-mineral supplement use and nutritional status of athletes. J Am Coll Nutr. 1993;12(2):162-9.

172. Beals KA, Manore MM. Nutritional status of female athletes with subclinical eating disorders. $J$ Am Diet Assoc. 1998;98:419-25.

173. Beitz R, Mensink GBM, Henschel Y, et al. Dietary behavior of German adults differing in levels of sport activity. Public Health Nutrition. 2004;7(1):45-52.

174. Striegel H, Simon P, Wurster C, et al. The use of nutritional supplements among master athletes. Int $\mathrm{J}$ Sports Med. 2006;27:236-41.

175. Giannopoulou I, Noutsos K, Apostolidis N, et al. Performance level affects the dietary supplement intake of both individual and team sport athletes. J Sports Sci Med. 2013;12:190-6.

176. Blackhouse SH, Whitaker L, Petroczi A. Gateway to doping? Supplement use in the context of preferred competitive situations, doping attitudes, beliefs, and norms. Scand J Med Sci Sports. 2013;23:244-52.

177. Wiens K, Erdman KA, Stadnyk M, et al. Dietary supplement usage, motivation, and education in young Canadian athletes. Int J Sports Nutr Exerc Metabol. 2014;24(6):613-22.

178. Sinclair LM, Hinton PS. Prevalence of iron deficiency with and without anemia in recreationally active men and women. J Am Diet Assoc. 2005;105:975-8.

179. Institute of Medicine. Dietary reference intakes for vitamin A, vitamin $\mathrm{K}$, arsenic, boron, chromium, copper, iodine, iron, manganese, molybdenum, nikel, silicon, vanadium, and zinc. Washington DC: National Academies Press; 2000.

180. Cogswell ME, Kettel-Khan L, Ranakrishnan U. Dietary supplement use among women in the United States: science, policy and practice. J Nutr. 2003;133:1974S-7S.

181. Vandenberghe K, Goris M, VanHecke P, et al. Long-term creatine intake is beneficial to muscle performance during resistance exercise. J Appl Physiol. 1997;83(6):2055-63.

182. Cermak NM, Res PT, de Groot LC, et al. Protein supplementation augments the adaptive response of skeletal muscle to resistance-type exercise training: a meta-analysis. Am J Clin Nutr. 2012;96:1454-64.

183. Subar AF, Block G. Use of vitamin and mineral supplements: demographics and amount of nutrients consumed. Am J Epidemiol. 1990;132(6):1091-101.

184. Slesinski MJ, Subar AF, Kahle LL. Trends in the use of vitamin and mineral supplements in the United States: the 1987 and 1992 National Health Interview Surveys. J Am Diet Assoc. 1995;95(8):921-3.

185. Millen AE, Dodd KW, Subar AF. Use of vitamin, mineral nonvitamin and nonmineral supplements in the United States: the 1987, 1992 and 2000 National Health Interview Survey results. J Am Diet Assoc. 2004;104:942-50.

186. Koplan JP, Annest JL, Layde PM, et al. Nutrient intake and supplementation in the United States (NHANES II). Am J Public Health. 1986;76(3):287-9.

187. Balluz LS, Kieszak SM, Philen RM, et al. Vitamin and mineral supplement use in the United States. Arch Fam Med. 2000;9:258-62. 
188. Radimer K, Bindewald B, Hughes J, et al. Dietary supplement use by US adults: data from the National Health and Nutrition Examination Survey, 1999-2000. Am J Epidemiol. 2004;160(4):339-49.

189. Kennedy ET, Luo H, Houser RF. Dietary supplement use pattern of US adult population in the 2007-2008 National Health and Nutrition Survey (NHANES). Ecol Food Nutr. 2013;52:76-84.

190. Knapik JJ, Steelman R, Hodedbecke S, et al. A systematic review and meta-analysis on the prevalence of dietary supplement use by military personnel. BMC Complement Altern Med. 2014;14:143.

191. Kennedy J, Arsenault J. Dietary supplement use in US Army Special Forces Operations Candidates. Mil Med. 1999;164(7):495-501.

192. Brasfield K. Dietary supplement intake in the active duty enlisted population. US Army Med Dep J. 2004, pp 44-56.

193. Boos CJ, Wheble GAC, Campbell MJ, et al. Self-administration of exercise and dietary supplements in deployed British military personnel during operation TELIC 13. J R Army Med Corps. 2010;156(1):32-6.

194. Lieberman HR, Stavinoha TB, McGraw SM, et al. Use of dietary supplements among active-duty US Army soldiers. Am J Clin Nutr. 2010;92(4):985-95.

195. Schutz HG, Read M, Bendel R, et al. Food supplement usage in seven Western states. Am J Clin Nutr. 1982;36:897-901.
196. Perkins JE, Wilson WJ, Schuster K, et al. Prevalence of nonvitamin, nonmineral usage among university students. J Am Diet Assoc. 2002;102(3):412-4.

197. Timbo BB, Ross MP, McCarthy PV, et al. Dietary supplements in a national survey: prevalence of use and reports of adverse events. J Am Diet Assoc. 2006;106:1966-74.

198. Huang SH, Johnson K, Pipe AL. The use of dietary supplements and medications by Canadian athletes at the Atlanta and Sydney Olympic Games. Clin J Sport Med. 2006;16(1):27-33.

199. Wu CH, Wang CC, Kennedy J. Changes in herb and dietary supplement use in the US adult population: a comparison of the 2002 and 2007 National Health Surveys. Clin Ther. 2011;33(11):1749-58.

200. Kelly JP, Kaufmann DW, Kelley K, et al. Recent trends in use of herbal and other natural products. Arch Intern Med. 2005;165:281-6.

201. Stensland SH, Sobal J. Dietary practices of ballet, jazz and modern dancers. J Am Diet Assoc. 1992;92:319-24.

202. Soric M, Misigoj-Durakovic M, Pedisic Z. Dietary intake and body composition of prepubescent female aesthetic athletes. Int J Sport Nutr Exerc Metab. 2008;18:343-54.

203. Kim J, Lee N, Jung SS, et al. Dietary supplementation of highperformance Korean and Japanese judoists. Int J Sport Nutr Exerc Metab. 2013;23:119-27.

204. Sekulic D, Bjelanovic L, Pehar M, et al. Substance use and misuse and potential doping behavior in rugby union players. Res Sports Med. 2014;22:226-39. 